CERE Working Paper, 2012:14

\title{
Elmarknaden och elprisets utveckling före och efter avregleringen: ekonometriska analyser
}

Runar Brännlund, ${ }^{\star}$ Amin Karimu* och Patrik Söderholm**

*Umeå universitet

CERE

Umeå School of Business and Economics

90187 Umeå

**Luleå tekniska universitet

Enheten för nationalekonomi

97187 Luleå

The Centre for Environmental and Resource Economics (CERE) is an inter-disciplinary and inter-university research centre at the Umeå Campus: Umeå University and the Swedish University of Agricultural Sciences. The main objectives with the Centre are to tie together research groups at the different departments and universities; provide seminars and workshops within the field of environmental \& resource economics and management; and constitute a platform for a creative and strong research environment within the field.

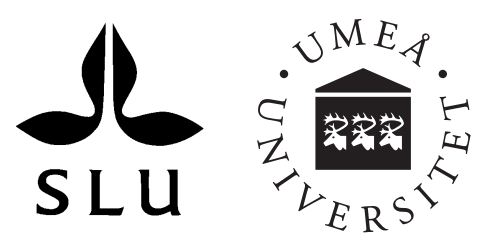

Department of Economics, Umeå University, S-901 87, Umeå, Sweden 


\title{
Elmarknaden och elprisets utveckling före och efter avregleringen: ekonometriska analyser ${ }^{*}$
}

\author{
31 maj 2012
}

\author{
Runar Brännlund,* Amin Karimu* och Patrik Söderholm** \\ *Umeå universitet \\ CERE \\ Umeå School of Business and Economics \\ 90187 Umeå \\ **Luleå tekniska universitet \\ Enheten för nationalekonomi \\ 97187 Luleå
}

\footnotetext{
* Denna rapport har genomförts på uppdrag av Näringsdepartementet. Författarna vill tacka Joakim Ceije, Magnus Thorstensson, Thomas Tangerås, samt Lennart Hjalmarsson för värdefull hjälp. Preliminära resultat från rapporten presenterades vid ett seminarium (elmarknadsdialog) på Näringsdepartementet i Stockholm den 10 maj 2012, och seminariedeltagarna bidrog där med ytterligare värdefull input. Eventuella felaktigheter och oklarheter skall dock endast tillskrivas författarna.
} 


\section{Inledning}

Det övergripande syftet med denna rapport är att med hjälp av ekonomisk teori och ekonometriska metoder försöka klargöra vilka faktorer som historiskt påverkat utvecklingen av elpriset. Av specifikt intresse är en analys av hur avregleringen 1996 påverkat elmarknaden och därmed utvecklingen av elpriset, samt $\mathrm{i}$ vilken utsträckning bl.a. skatter och elcertifikat påverkat konsumentpriset senare år. Analysen belyser elprisets utveckling på såväl årsbasis (under perioden 1970-2010) samt på månadsbasis (under perioden januari t.o.m. december 2010).

Det pris som konsumenter av el slutligen betalar beror på ett samspel mellan ett flertal marknader, politiska beslut och andra omvärldsfaktorer. Elmarknaden, som vi här definierar som den marknad där el säljs av elproducenter och köps av elhandelsbolag, är en del i den komplexa bilden. Det svenska elpriset bestäms i huvudsak på en nordisk elmarknad men flaskhalsar i överföringskapaciteten kan ibland ge upphov till viktiga prisskillnader länder emellan. Andra delar som är relevanta ur ett konsumentperspektiv är distributionskostnader för el, den så kallade nätavgiften, och elcertifikatmarknaden. Här kommer vi i huvudsak att fokusera den mer renodlade elmarknaden inklusive skatter och elcertifikat. Eldistributionssidan kommer vi inte att fördjupa oss i; nivån på nättarifferna är reglerade och de har varit mer eller mindre konstant $\mathrm{i}$ reala termer under den period som analyseras här (se vidare avsnitt 2). Vidare kommer vi inte heller att ge någon djupare analys av den s.k. elhandelsmarknaden. Konkurrensen på elmarknaden (produktion och handel) kommer att belysas kort, och slutsatser från litteraturen på området kommer att ligga till grund för slutsatser vad gäller konkurrenssituationen.

I avsnitt 2 redogör vi för utvecklingen på elmarknaden, dvs. hur produktion, konsumtion och priser utvecklats över tiden. Här belyses även mer betydande politiska och institutionella reformer. I avsnitt 3 ger vi en enkel konceptuell beskrivning av elmarknadens funktionssätt, vilken prisbildningen vilar på. Syftet är dels att redogöra för viktiga utgångspunkter, dels att illustrera principer som är viktiga för prisbildningen.

I avsnitt 4 fördjupar och specificerar vi den konceptuella analysen genom att presentera och tillämpa en enkel numerisk modell av den nordiska elmarknaden. Vi använder modellen för att illustrera de möjliga effekterna av: (a) en avveckling av den svenska kärnkraften; samt (b) en utfasning av det svenska elcertifikatsystemet. Den senare delen belyser också generellt elcertifikatens effekter på elmarknaden samt samspelet mellan certifikatmarknaden och elmarknaden.

Med utgångspunkt i tidigare avsnitt redogör vi sedan i avsnitt 5 för resultaten från två ekonometriska modeller vars syfte är att förklara den faktiska prisutvecklingen före såväl som efter avregleringen 1996. Grundläggande frågeställningar här är: (a) har avregleringen av elmarknaden (allt annat lika) lett till högre eller lägre priser; samt (b) hur stor del av prisförändringarna kan förklaras av förändrade skatter och införandet av elcertifikat och EU-ETS, samt av kapacitetsbrister/högre kostnader i eltillförseln? I en första del specificerar vi en ekonometrisk modell som med hjälp av en rad utbuds- och efterfrågepåverkande variabler försöker förklara utvecklingen av det årliga konsumentpriset under perioden 1970-2010 samt explicit testa för ett trendbrott vid tiden för avregleringen. Sedan estimeras även en modell baserat på månatliga elpriser inom 
Nordpool sedan avregleringen 1996. Denna modell belyser också betydelsen av olika efterfråge- samt utbudsfaktorer, och försöker också (indirekt) estimera priseffekterna av flaskhalsar i överföringskapaciteten mellan de nordiska länderna.

\section{Elmarknaden, en deskriptiv bakgrund}

\subsection{En historisk tillbakablick}

Elektrifieringen av vårt samhälle är nog en av de saker, tillsammans med ångmaskinen, som bidragit mest till utvecklingen och vår välfärd de senaste 100 åren. Det första användningsområdet för el i Sverige för runt 150 år sedan var som energikälla för ljus. Fram till början av 1900-talet var i stort sett all elanvändning kopplat till ljus. Nämnas kan att år 1876 lystes Näs sågverk i Dalarna och Marma sågverk i Hälsingland upp utomhus av elektriskt ljus med båglampor. Det var första gången i Sverige som elektriskt ljus togs i praktiskt bruk. Elektriciteten genererades dock av en ångmaskin. Nästa stora användningsområde för den elektriska energin blev för motordrift. Först i Sverige med att installera en elmotor var Arboga Mekaniska Verkstad som år 1887 bytte ut ångmaskinen mot en elmotor för drift av verktygsmaskiner. ${ }^{1}$ På 1890-talet började industriföretag bygga egna kraftverk i större skala i syfte att övergå till eldrift. Det var framförallt järnverk i Bergslagen, massafabriker och pappersbruk. Det statliga kraftverksbyggandet startade i början av 1900-talet. I och med ASEA's utveckling av trefas växelström blev det möjligt att överföra el över längre avstånd. Senare utvecklades överföring av högspänd likström, vilket banade vägen för utbyggnaden av vattenkraften i Sverige. Utbyggnaden av vattenkraften inleddes i södra och mellersta Sverige, men det var i övre Norrland arbetet med att bygga större kraftstationer inleddes 1910 (Porjus, Lule älv). Efter det kom Indalsälven på 1920-talet, och utvecklingen fortsatte sedan i snabb takt. Vattenkraften var mer eller mindre fullt utbyggd på 1960-talet. I samband med detta började kärnkraftseran där det första kärnkraftverket i Ågesta stod klart 1963. Från mitten av 1970-talet till mitten av 1980-talet byggdes tolv större reaktorer, och idag svarar kärnkraften för nära hälften av elproduktionen (se vidare avsnitt 2.3).

\subsection{Elanvändningen}

Utvecklingen av elkonsumtion (och produktion) sammanfattas i figur 2.1. Som framgår ökade elkonsumtionen (och produktionen) exponentiellt fram till slutet av 1980-talet. Den tekniska utvecklingen i kombination med naturliga förutsättningar för elproduktion (vattenkraft) är en förklaring till utvecklingen, som också i stora drag kan förklara industrialiseringen av Sverige och den ekonomiska utvecklingen de senaste 100 åren. Sedan mitten av 1960-talet och fram till slutet av 1980-talet växte elanvändningen snabbare än BNP, men under de senaste två decennierna uppvisar i stället BNP en betydligt högre tillväxttakt än elanvändningen.

\footnotetext{
${ }^{1}$ Hult. J., och Rydberg, S. (1989). Svensk Teknikhistoria. Gidlunds förlag.
} 


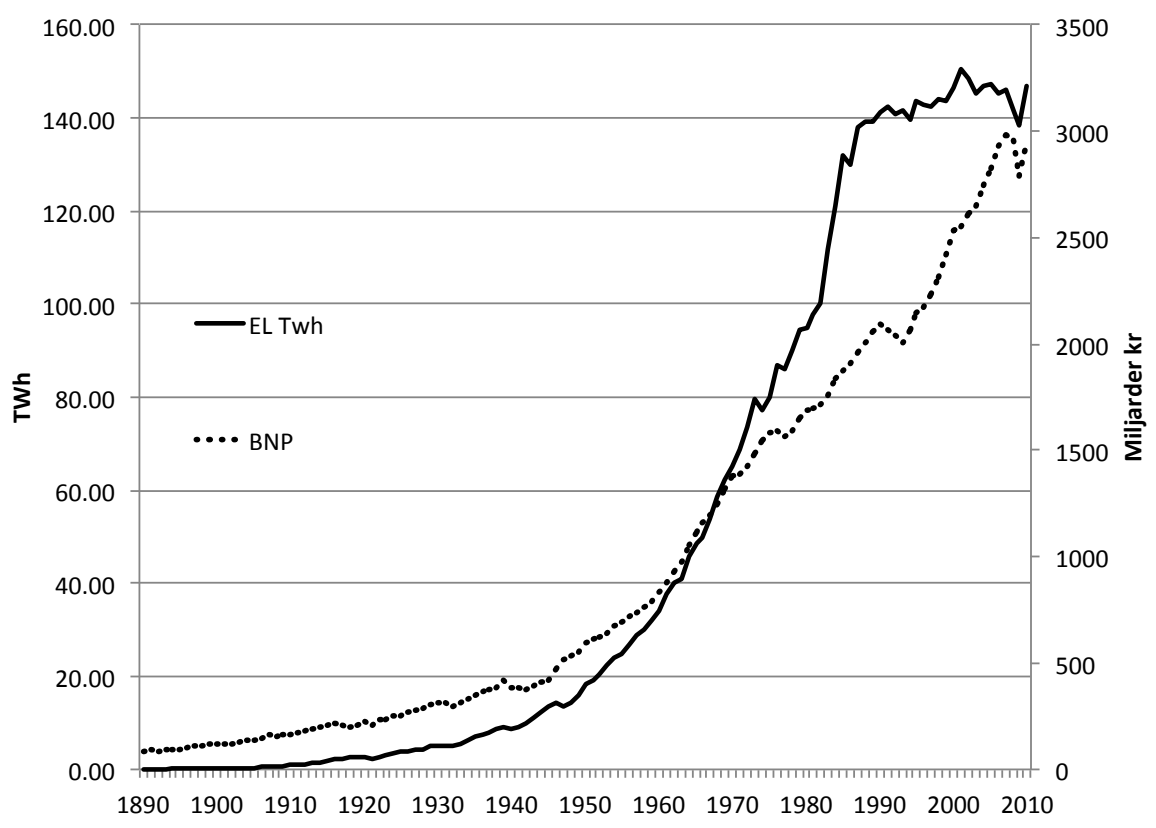

Figur 2.1: Elkonsumtionen och BNP i Sverige 1890-2010 (Källa: Kander, A., och Lindmark, M. (2004). "Energy Consumption, Pollutant Emissions and Growth in the Long Run - Sweden during 200 years," European Review of Economic History, Vol. 8, s. 297-335).

Utvecklingen av elkonsumtionen de senaste 40 åren, och hur den fördelas på olika sektorer redovisas i figur 2.2. Figuren visar bland annat att stagnationen i elanvändningen sedan 1980-talet kan förklaras av måttliga ökningar i de flesta sektorer.

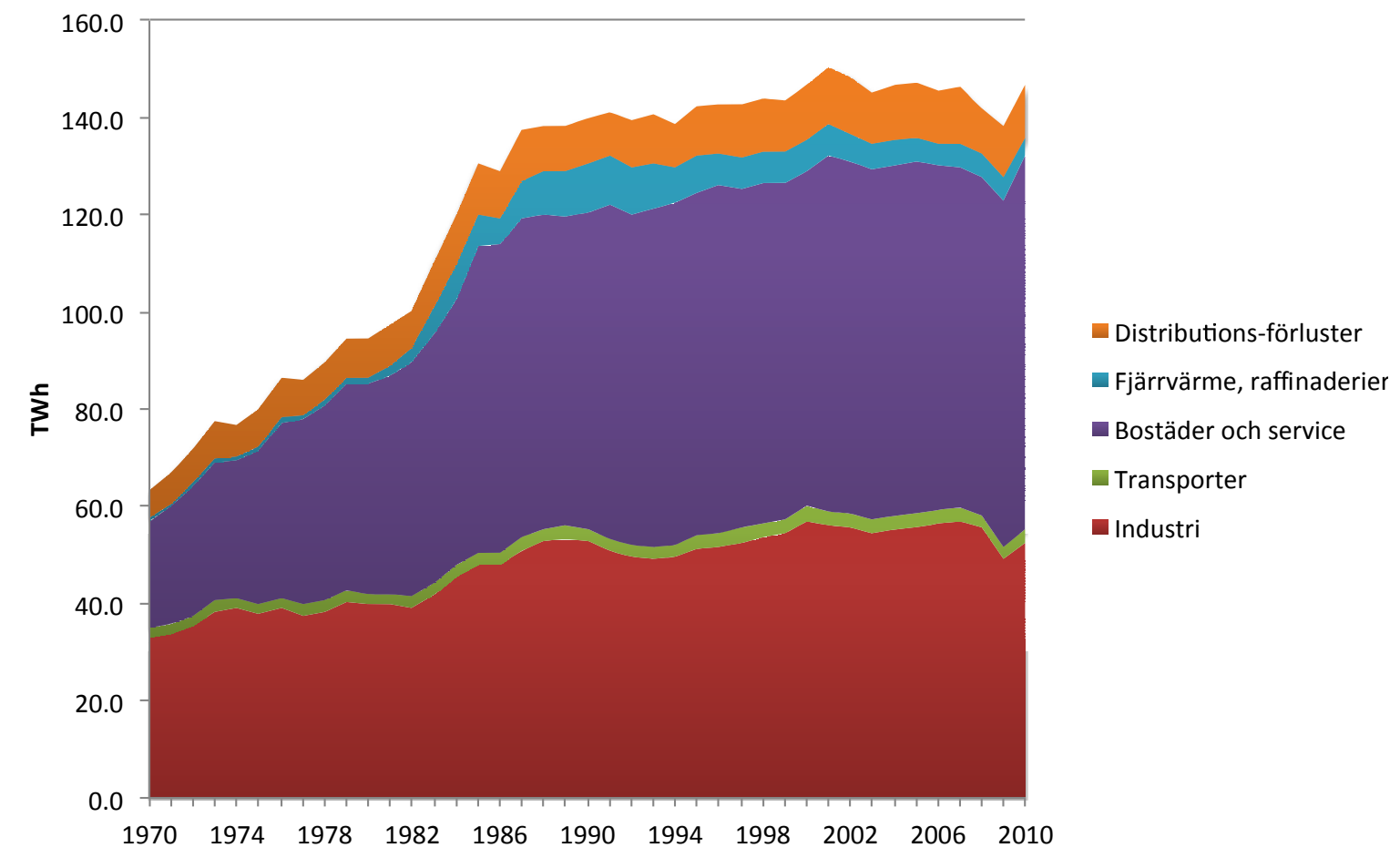

Figur 2.2: Elkonsumtionens fördelning på sektorer, 1970 - 2010. (Källa: Energiläget $i$ siffror, Energimyndigheten) 
År 1970 var industrins andel av elkonsumtionen cirka $52 \%$. Av resterande $48 \%$ svarade bostäder och service för cirka $35 \% .40$ år senare är fördelningen den omvända, industrins andel är då $37 \%$, medan bostäder och service svarar för $48 \%$. Det bör även noteras att det skedde ett trendbrott $\mathrm{i}$ bostads och servicesektorns elanvändning i början på 1980-talet, i meningen att ökningstakten i elanvändningen minskat signifikant. Till stor del kan detta förklaras av uppvärmningen av hus och bostäder som konverterats från el till fjärrvärme, biobränslen och olika slag av värmepumpar.

Sammantaget betyder detta att den specifika elanvändningen, mätt som elförbrukning per BNP-enhet, minskat kraftigt de senaste 30 åren. Detta gäller för de flesta sektorer.

\subsection{Eltillförseln}

Fram till 1970-talet dominerades eltillförseln fullständigt av vattenkraften. Vid den tiden fanns en hel del oljeeldade kraftverk som dock till stor del fasades ut i samband med oljekriserna under 1970-talet. Kärnkraftsutbyggnaden startade på allvar i mitten av 1970-talet, och idag svarar kärnkraften för nära hälften av eltillförseln (se figur 2.3). Vindkraftsutbyggnaden, som tagit fart på allvar under de senaste 7-8 åren, svarar idag (december 2011) för cirka 6 TWh, vilket utgör cirka $4 \%$ av den totala tillförseln av el i Sverige. ${ }^{2}$ En viktig förklaring till vindkraftens utbyggnad är introduktionen av elcertifikatsystemet 2003, och inte minst den reformering av certifikatsystemet som genomfördes 2006.

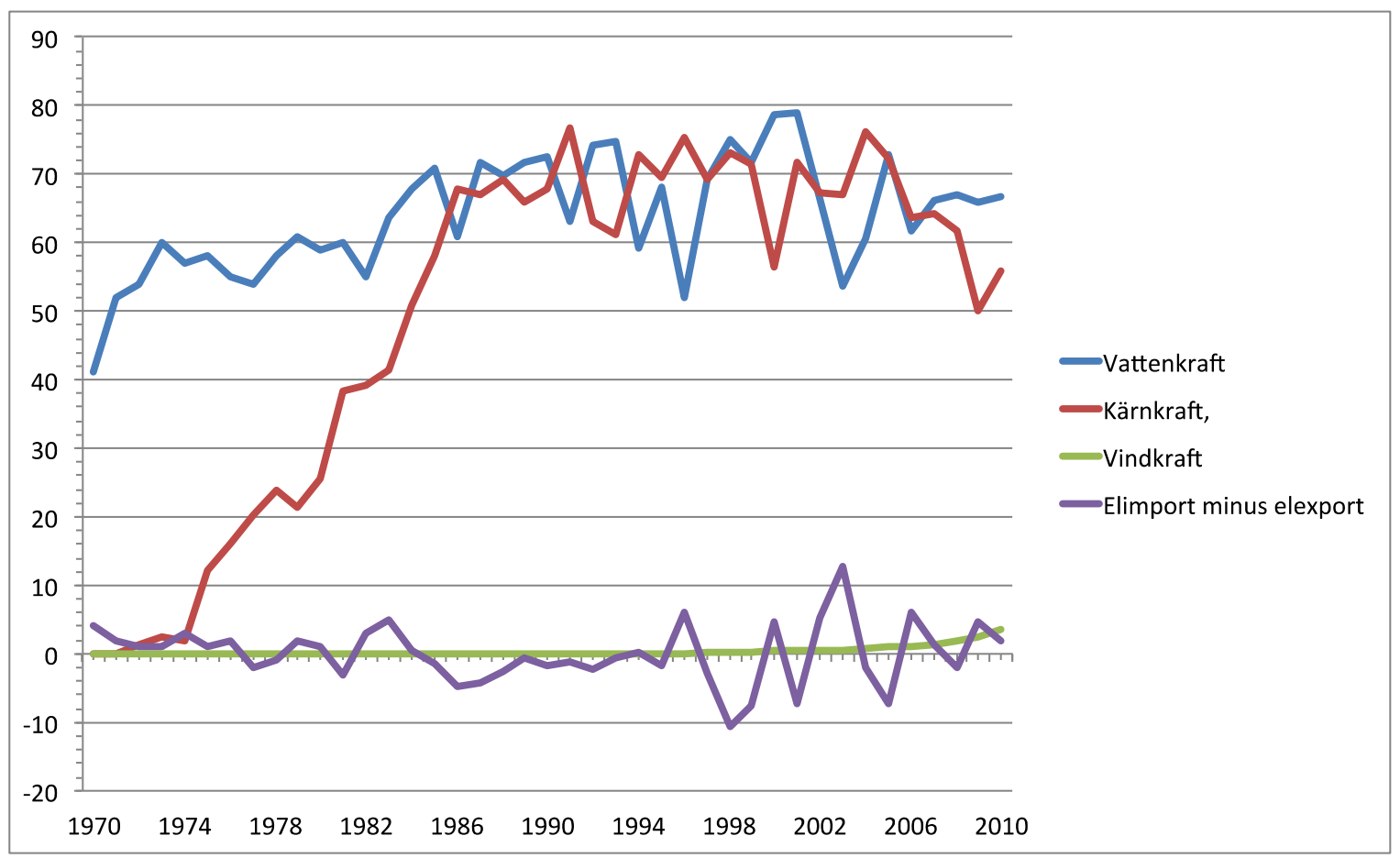

Figur 2.3: tillförsel av el i Sverige, 1970-2010 (Källa: Energiläget $i$ siffror, Energimyndigheten)

Värt att notera är de stora variationerna i tillförseln från vattenkraft. Huvudförklaringen är variationer i det hydrologiska systemet. Variationerna i kärnkraftsproduktion under

\footnotetext{
${ }^{2}$ Energimyndigheten (2011). Vindkraftsstatistik 2011, ES 2012:02, Eskilstuna.
} 
1990- och 2000-talet brukar vanligtvis förklaras med att kärnkraftverken är gamla och slitna och det av detta skäl är många och långa driftsstopp. En annan förklaring som förts fram är att kärnkraftsstoppen används i strategiskt syfte från ägarna av kärnkraften, dvs. till att pressa upp priset på el. Vi återkommer till denna fråga $\mathrm{i}$ avsnitt 4 , men konstaterar redan nu att ägarstrukturen i den svenska elproduktionsapparaten kan ge incitament till att i vissa tider köra kärnkraften på sparlåga.

\subsection{Elprisets utveckling}

Efter avregleringen 1996 bestäms priset på el i princip på samma sätt som på andra marknadsprissatta varor, dvs. av samspelet mellan utbud och efterfrågan. Liksom för många andra marknader kan man säga att elmarknaden är komplex i så måtto att den, $\mathrm{i}$ alla fall ur ett elkonsumentperspektiv består av flera delar, eller delmarknader, vars samverkan sammantaget bestämmer det pris elkonsumenten slutligen făr betala för sin elanvändning. Den första delmarknaden är själva kraftmarknaden medan den andra delmarknaden är elleveransmarknaden, eller återförsäljarmarknaden. Den tredje delmarknaden som är av betydelse är marknaden för elcertifikat, som har en direkt påverkan på det pris som elkonsumenten slutligen får betala. Vi skulle även kunna lägga till utsläppsrättighetsmarknaden (EU-ETS), som indirekt påverkar elmarknaden genom att den påverkar priset på fossila bränslen som till viss del används till att producera el. När man pratar elpris, eller hushållens elkostnad, brukar man också lägga till kostnaden för distributionen av el som bestäms av den så kallade nätavgiften. Marknaden för eldistribution är en reglerad marknad som kan sägas bestå av två delar; dels stomnätet som ägs av staten via Svenska Kraftnät, dels det regionala och lokala näten som ägs och drivs av privata bolag. I figur 2.4 redovisas utvecklingen av det slutliga priset på el, inklusive skatter, elcertifikatskostnad samt nätavgift för hushållskunder (för kunder med rörligt pris).

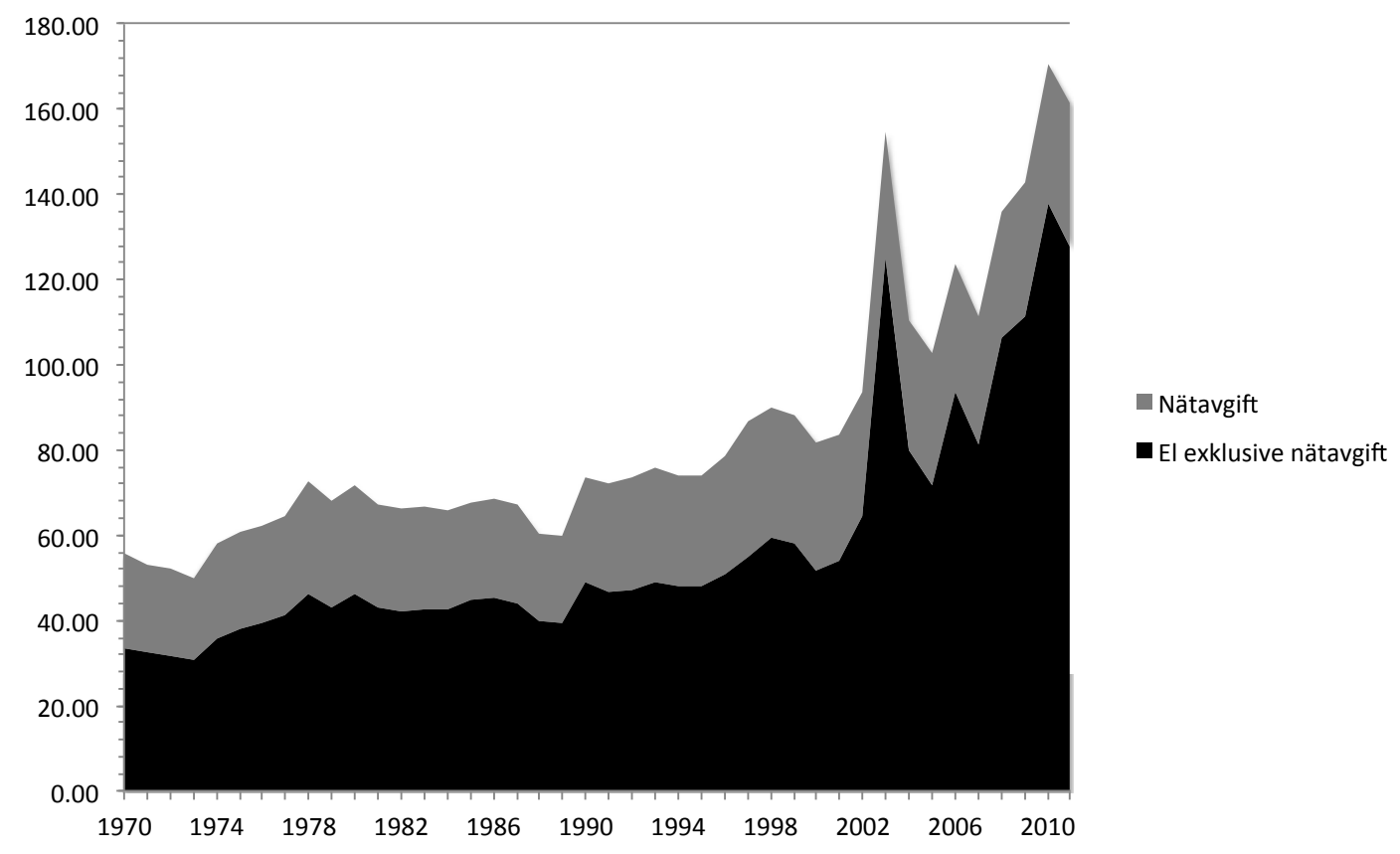

Figur 2.4: Konsumentpriset på el och eldistribution för hushållskund, inklusive skatter och elcertifikatsavgift, 1970-2011 uppdelat på elpris och nätavgift. Öre per KWH (2010 års priser). (Källa: Svensk Energi). 
Figur 2.4 visar att en hushållskunds kostnad för el (el plus nät) har stigit från knappt 60 öre/kWh 1970 till cirka 160 öre år 2010. Vidare visar samma figur att priset stigit trendmässigt sedan 1970-talet och att ökningen främst kan tillskrivas ett ökat elpris (inklusive skatter och elcertifikatsavgifter). ${ }^{3}$ Nätavgiften har varit i stort sett konstant $\mathrm{i}$ reala priser. Vidare kan vi konstatera att såväl prisökningstakten som prisvariationen ökat under 2000-talet. Vi återkommer till förklaringarna till detta senare, men kan redan nu konstatera att stora variationer i klimat mellan åren och driftsproblem i kärnkraften förmodligen är bidragande orsaker till utvecklingen under 2000 -talet. ${ }^{4}$ Det kan t.ex. nämnas att pristoppen under vintern 2002/2003 till stora delar förklaras av betydande underskott $\mathrm{i}$ vattenmagasinen $\mathrm{i}$ kombination med hög efterfrågan; under hösten och vintern 2002 var det sammanlagda tillflödet i det nordiska elsystemet ungefär hälften av det normala. ${ }^{5}$ Detta är unikt lågt $i$ ett historiskt perspektiv. De höga priserna under 2010 beror till stora delar på problem i kärnkraften med flera och utdragna stopp; under året uppgick kärnkraftsproduktionen till endast drygt $55 \mathrm{TWh}$, vilket t.ex. kan jämföras med 2004 års nivå på ca 75 TWh.

År 2003 infördes kvotplikten på förnyelsebar el och tillhörande elcertifikatmarknad, vilket gav en direkt positiv effekt på priset (se figur 2.5). Kvotplikten i certifikatsystemet innebär samtidigt att en viss andel nyproduktion tillförs systemet, vilket därmed kan ha en dämpande effekt på marknadspriset på el. Nettoeffekten av dessa två motverkande effekter på konsumentpriset är osäker, och vi återkommer till denna fråga i avsnitt 4. År 2005 startade dessutom den Europeiska utsläppsmarknaden för koldioxid (EU-ETS), vilket kan ha bidragit till utvecklingen av högre elpriser under senare år. Förklaringen är att elpriset i Norden till stora delar bestäms av kostnaden för gas- och kolkondens, vilken stiger då koldioxiden uppbär ett positivt pris.

I figur 2.5 redovisas hur elpriset (dvs. konsumentpriset exklusive nätavgift) utvecklats perioden 1970-2011, samt hur fördelningen mellan producentpris och skatter (inklusive elcertifikat) utvecklats. Vi kan konstatera att skattens andel av priset ökat fram till början av 2000-talet för att sedan vara mer eller mindre konstant, även om den ökat $\mathrm{i}$ absoluta tal (i reala priser). 1970 var skatten på el knappt 4 öre per KWh (i 2010 års penningvärde), för att stiga till knappt 56 öre $2010 .{ }^{6} \mathrm{Vi}$ ser också att den direkta effekten av elcertifikatssystemet som infördes 2003 är cirka 5 öre per KWh.

\footnotetext{
${ }^{3}$ Det kan noteras att i ett historiskt perspektiv är 1970 års elpris på en mycket låg nivå. I början av 1920-talet fick ett svenskt hushåll betala nästan 6 kronor för en kWh elenergi (i 2010 års priser). Se t.ex. Bergman, L., T. Hartman, L. Hjalmarsson, och S. Lundgren (1994). Den nya elmarknaden, SNS förlag, Stockholm; samt Nilsson, I. (2009). Unit Root Tests and Structural Breaks in the Swedish Electricity Price, Magisteruppsats i nationalekonomi, Luleå tekniska universitet.

${ }^{4}$ Övergången från en reglerad marknad till en marknad där utbud och efterfrågan helt får styra produktion och pris har förmodligen också bidragit till ökad volatilitet, se Lundgren (2009) och Dempster (2012).

${ }^{5}$ Damsgaard, N., och R. Green (2005). Den nya elmarknaden. Framgång eller misslyckande? SNS förlag, Stockholm.

${ }^{6}$ Konsumtionsskatten på el som redovisas avser hushåll i "övriga Sverige". Hushållskunder i vissa kommuner i norra Sverige har en lägre skatt (10 öre lägre per $\mathrm{kWh}$ ).
} 
Figurerna 2.4 och 2.5 visar tydligt på en realprisökning för el sedan tiden för avregleringen, men detta är i sig inget bevis för att avregleringen haft en (allt annat lika) prishöjande effekt. En rad faktorer som påverkar priset har förändrats över tiden (se ovan), och den enda meningsfulla jämförelsen är att vid en given tidpunkt jämföra den prisnivå som gäller under konkurrensutsatta förhållanden med motsvarande prisnivå under reglerad marknadsstruktur. Detta utgör en ganska komplicerad kontrafaktisk analys, som vi kommer att återkomma till i avsnitt 5.

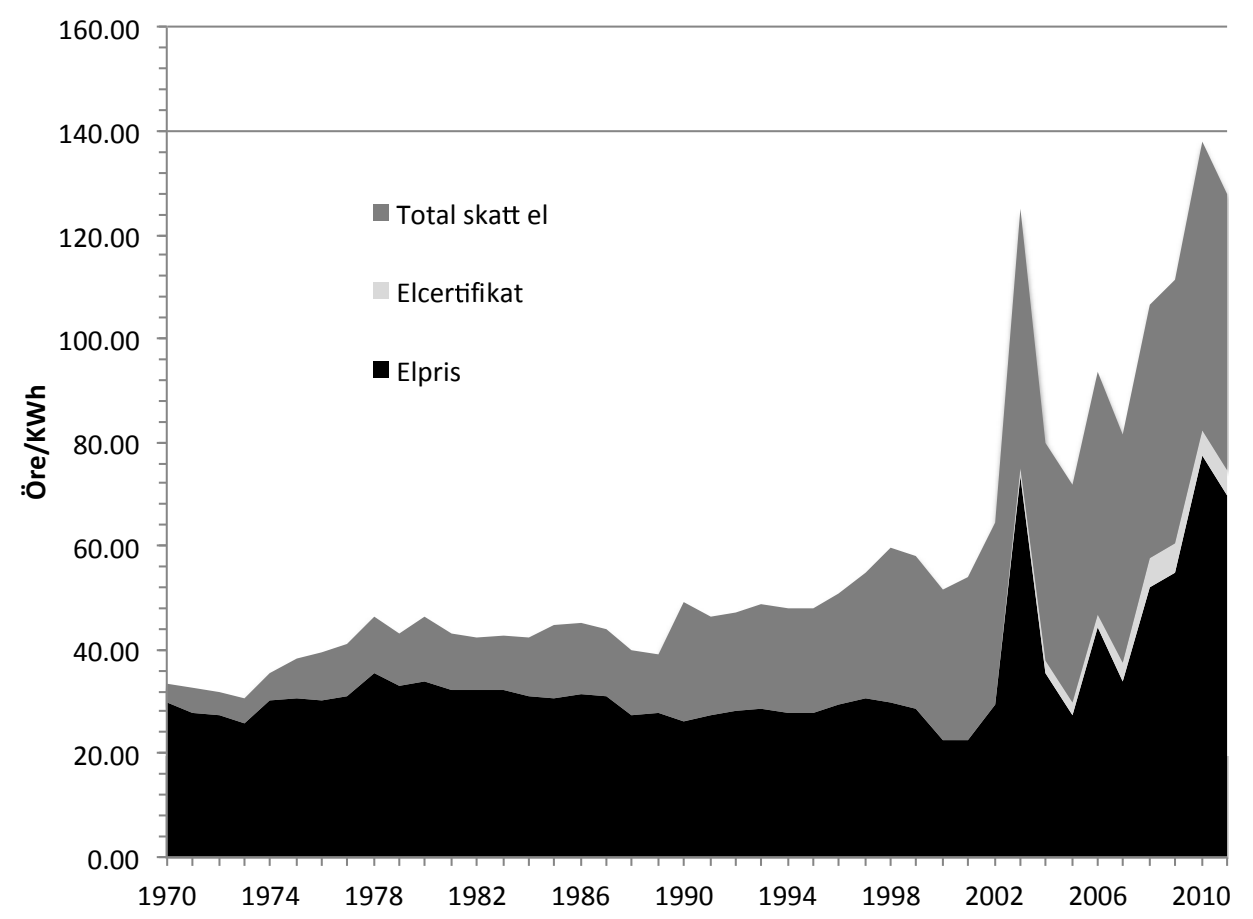

Figur 2.5: Konsumentpriset på el för hushållskund, exklusive nätavgift, 1970-2011 uppdelat på producentpris, skatt inklusive moms och elcertifikatsavgift. Öre per kWh (2010 års priser). (Källa: Svensk Energi)

Sammantaget kan konstateras att vi sedan 1970 haft ett trendmässigt stigande realt konsumentpris på el, och att den största uppgången skett från början av 2000-talet. Ser man till det rena råkraftpriset på marknaden så visar det en något annorlunda bild med realt fallande pris fram till början av 2000-talet för att sedan stiga relativt kraftigt. Det stigande konsumentpriset fram till början av 2000-talet kan framförallt förklaras av ökade skatter.

\section{Elmarknadens funktionssätt}

Ovan har vi redogjort för användningen och tillförseln av el i det svenska elsystemet, samt utvecklingen av konsumentpriset. Användningen, såväl nivå som fördelning, bestäms självfallet av konsumenternas efterfrågan, som i sin tur påverkas av bl.a. betalningsförmåga och priset på el. Tillförseln å andra sidan är avhängig bl.a. produktionskostnaderna och priset på el. På den nu avreglerade (eller snarare omreglerade) marknaden kan vi säga att den konsumtion och tillförsel vi observerar vid en given 
period är den punkt där elkonsumenternas marginella betalningsvilja för el är lika med elproducenternas marginalkostnad för att producera elen i det sammanlänkade nordeuropeiska elsystemet. Det är i denna punkt det så kallade "systempriset" på el ges. Det slutliga elpriset på enskilda delmarknader, exempelvis den svenska, beror dessutom på möjligheterna att transportera el från det ställe där elen tillförs elsystemet till det ställe den skall användas. Det betyder i praktiken att priserna periodvis kan vara högre i vissa områden och lägre i andra.

\subsection{Elmarknaden före 1996}

Prisbildningen på el före avregleringen 1996 kan beskrivas utifrån situationen på de två delmarknaderna; kraftmarknaden respektive elleveransmarknaden (alternativt högspännings- samt lågspänningsmarknaderna). På kraftmarknaden bestämdes priset av statens avkastningskrav på Vattenfall eftersom Vattenfall var prisledande på marknaden. Detta satte väsentligen ett tak på kraftpriserna, men det samarbete som förekom mellan kraftbolagen innebar också att tillträdet till marknaden kunde begränsas och bidra till att hålla uppe priset.

Tidigare studier visar att prissättningen på kraftmarknaden var förhållandevis effektiv. En effektiv prissättning innebär att fasta avgifter endast används för att uppfylla budgeteller avkastningskrav medan de rörliga avgifterna ska reflektera de kortsiktiga marginalkostnaderna. Denna princip anammades framgångsrikt på den reglerade marknaden. Simuleringar visar t.ex. att elprisnivån endast var något högre än jämviktspriset vid fullständig konkurrens (då priset är lika med marginalkostnaden), men samtidigt var priserna betydligt lägre än vad de skulle ha varit om kraftföretagen hade utnyttjat sin marknadsmakt full ut. ${ }^{7}$

På elleveransmarknaden fanns också viss konkurrens (s.k. yardstick competition) men här var inslaget av genomsnittskostnadsprissättning tydligare, inte minst genom juridiska krav i ellagen om "skälig prissättning" samt den s.k. självkostnadsprincipen i kommunallagen.

\subsection{Elmarknaden efter 1996}

Av- eller omregleringen av elmarknaden syftade $\mathrm{i}$ huvudsak till att öka effektiviteten $\mathrm{i}$ produktions- och försäljningsledet genom att skapa konkurrens i både produktionsledet och återfösäljarledet, bl.a. genom att ge elkonsumenterna frihet vad gäller val av elleverantör. ${ }^{8}$ De regler som infördes den 1 januari 1996 innebar att konkurrens infördes i såväl elhandel och elproduktion. Syftet var som sagt att bl.a. införa valfrihet för elkonsumenterna och skapa förutsättningar för en ökad pris- och kostnadspress inom elförsörjningen. Regleringar som hindrade handel med el avskaffades, medan eldistributionen även fortsättningsvis skulle regleras och övervakas. Skälet till det senare var (och är) att eldistributionen karakteriseras av fallande marginalkostnader, och därmed

\footnotetext{
${ }^{7}$ Se Bergman, L., T. Hartman, L. Hjalmarsson, och S. Lundgren (1994). Den nya elmarknaden, SNS förlag, Stockholm.

${ }^{8}$ Omregleringen startade redan 1992 då Statens Vattenfallsverk ombildades till Vattenfall AB, samtidigt som nyinrättade Affärsverket Svenska Kraftnät övertog ansvaret för stamnätet (se SOU 2002:7).
} 
kan betraktas som ett naturligt monopol. Det betyder att marginalkostnadsprissättning inte är möjligt eftersom en sådan prissättning innebär att kostnaderna inte kommer att täckas fullt ut. En av grundbultarna i den reformerade elmarknaden var åtskillnaden mellan å ena sidan produktion och försäljning av el och å andra sidan nätverksamhet, distributionen. En juridisk person som producerar och säljer el får helt enkelt inte bedriva nätverksamhet. Visserligen kan nätföretag bedriva annan verksamhet än elproduktion och handel, men då är kravet att nätverksamheten skall särredovisas. Det grundläggande syftet med dessa bestämmelser är att undvika att nätverksamheten belastas med kostnader för annan verksamhet (s.k. korssubventionering). Sådan korssubventionering förekom under den reglerade perioden, t.ex. genom att vinster från eldistribution fick täcka kostnader i förlustbringande verksamheter inom kommunal kraftvärme- och värme.

I och med av- eller omregleringen 1996 blev den svenska elproduktionen integrerad med den norska när man gick med i Nordpool som är en gemensam marknadsplats för el. Finland gick med 1998 och år 2000 hade hela Danmark anslutit sig. Avregleringen 1996 och den gemensamma nordiska marknadsplatsen innebär därmed de facto att priset på el timme för timme bestäms av utbud och efterfrågan på el. Priset på el, som sätts under auktionsliknande former, bestäms således av utbud och efterfrågan. Om tillgänglig överföringskapacitet $i$ nätet begränsar överföringar mellan olika delar av Nord Pool-området måste marknaden delas. Då sätts ett pris för varje delområde, samt ett systempris som skulle gälla om inga begränsningar fanns i överföringskapacitet. Systempriset används ofta som referens för prisnivån på elbörsen, samt som underliggande pris för de flesta finansiella kontrakt. Fram till november 2011 var Sverige som helhet ett delområde. Från och med november 2011 har dock Sverige delats in i fyra "prisområden" (SE1-SE 4).

Prisbildningen på Nordpol kan enklast förklaras med en principiell skiss av elmarknaden. I figur 2.6 illustreras marknadens utbud av el i en given tidpunkt av den positivt lutande trappstegskurvan (marginalkostnadskurvan). Trappsteget längst ned till vänster representerar den elproduktion som har lägst marginalkostnad, medan den längst upp till höger representerar den elproduktion där kostnaden är högst. Trappstegsfunktionen kan därmed ses som en rangordning av produktionskapacitet, från den med lägst kostnad till den med högst. Den negativt lutande linjen i diagrammet är en hypotetisk efterfrågekurva. Den visar hur stor efterfrågan på el är vid olika prisnivåer. Den kan också sägas representera den marginella betalningsviljan för el vid varje given konsumtionsnivå. I diagrammet har vi lagt in två hypotetiska efterfrågekurvor, en som vi kallar "efterfrågan sommar" och en "efterfrågan vinter". Eftersom sommaren är (relativt) varm är efterfrågan (relativt) låg. Alternativt kan man säga den marginella betalningsviljan för el ökar när vintern kommer.

Givet "efterfrågan sommar" kommer elproduktionsanläggningar med en marginalkostnad lägre är P0 att producera el. Produktionsanläggningar med högre marginalkostnad kommer inte att tas i bruk eftersom inte betalningsviljan finns. Det betyder att det pris som kommer att etableras på sommaren är lika med P0. Tittar vi lite extra länge på diagrammet står klart att vid det priset maximeras summan av konsument- och producentöverskott, eller om man så vill kan man säga att produktions (och konsumtions) volymen Q0 är den samhällsekonomiskt effektiva volymen. Vi ser också att det 
betyder att de kraftslag med lägst kortsiktiga marginalkostnader (t.ex. vindel, vattenkrafts- och kärnkraftsel) kommer att få ett relativt stort överskott för att täcka fasta kostnader och ge eventuellt stora vinster. Den anläggning som ligger på marginalen kommer dock inte att tjäna några pengar av betydelse ens på kort sikt. Ett av huvudsyftena med avregleringen var att få till stånd en allokering av elproduktionen på ett sätt som i princip överensstämmer med illustrationen i figur 3.1.

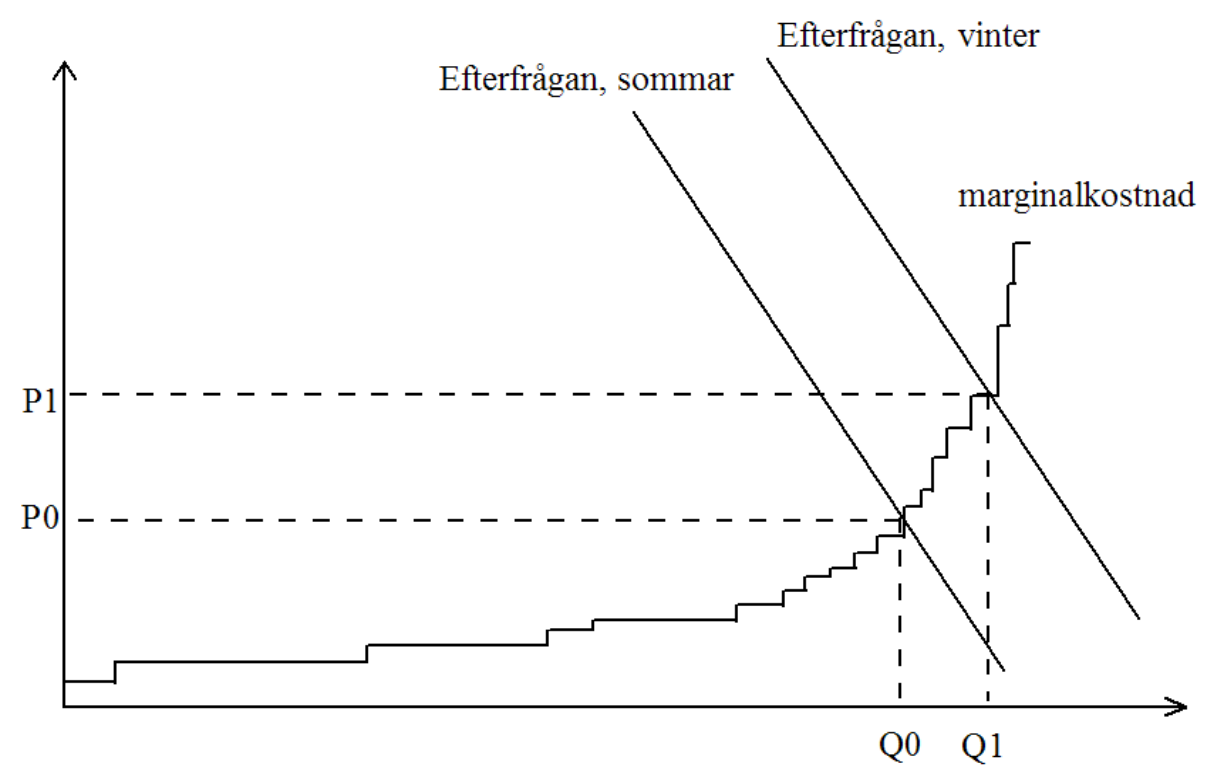

Figur 3.1: En principskiss av elmarknaden

På sommaren är elefterfrågan såsom påpekas ovan relativt låg, vilket innebär att produktionsanläggningar med höga kostnader inte kommer att tas i drift och priset på el kommer därmed att bli relativt lågt. Till vintern ökar dock efterfrågan, efterfrågekurvan skiftar utåt, vilket betyder att konsumenterna är villiga att betala mer för att få ytterligare el. Det betyder i sin tur att det blir lönsamt att producera i anläggningar med högre marginalkostnad, vilket då betyder att jämviktspriset stiger till P1. Hur mycket priset kommer att förändras mellan exempelvis sommar och vinter beror till stor del på hur "brant" trappstegskurvan är. Är den väldigt brant, dvs. vi är nära det totala kapacitetstaket i elproduktionen kommer prisförändringen att bli stor, dvs. priset över året kommer att variera relativt kraftigt. Det omvända gäller givetvis om funktionen är "flack", vilket betyder att vi kan öka produktionen utan att kostnaderna ökar särskilt mycket. En viktig "säsongsfaktor" i det nordiska elsystemet är produktionskapaciteten i vattenkraftssystemet. Har sommar och höst varit torra innebär det låg fyllnadsgrad i vattenmagasinen, vilket innebär låg produktionskapacitet under vintern. Sammantaget kan vi konstatera att om marknaden fungerar såsom beskrivs i figur 3.1 så kan vi på grund av säsongsmässiga fluktuationer i efterfrågan och produktionskapacitet komma att observera relativt stora säsongsmässiga prisvariationer.

Om marknaden fungerar på det sätt som illustreras i figur 3.1 kommer generellt sett den elproduktion som efterfrågas att produceras till minsta möjliga kostnad. En central fråga är därmed om vi kan tro att den fungerar på det sätt som beskrivs, eller om det finns starka skäl till att tro att den inte gör det? Vi återkommer senare i rapporten med en 
något djupare analys av denna fråga, men ett första enkelt test är att helt enkelt titta efter om priset varierar mycket eller litet över året. Vi vet att under vinterhalvåret utnyttjas den så kallade baskraften fullt ut (om inte kärnkraftverken av olika skäl ställts av). Det betyder att om marknaden fungerar någorlunda på det sätt som beskrivits borde elpriset fluktuera relativt kraftigt eftersom en efterfrågeökning (p.g.a. av några extra kalla dagar exempelvis) innebär att produktionsanläggningar med höga kostnader måste tas i bruk. Exempelvis har det inte varit helt ovanligt att oljeeldade aggregat som vanligtvis inte används har tagits i bruk temporärt, och till höga kostnader. Detta borde då leda till att priset stiger kraftigt.

I figur 3.2. redovisas det genomsnittliga marknadspriset per månad på Nordpool för perioden 1996 till 2011. Två priser redovisas, systempriset och priset i Sverige. Dessa två priser sammanfaller om marknaden fungerar på det sätt vi beskrivit samt om det går att överföra el mellan olika områden utan begränsningar.

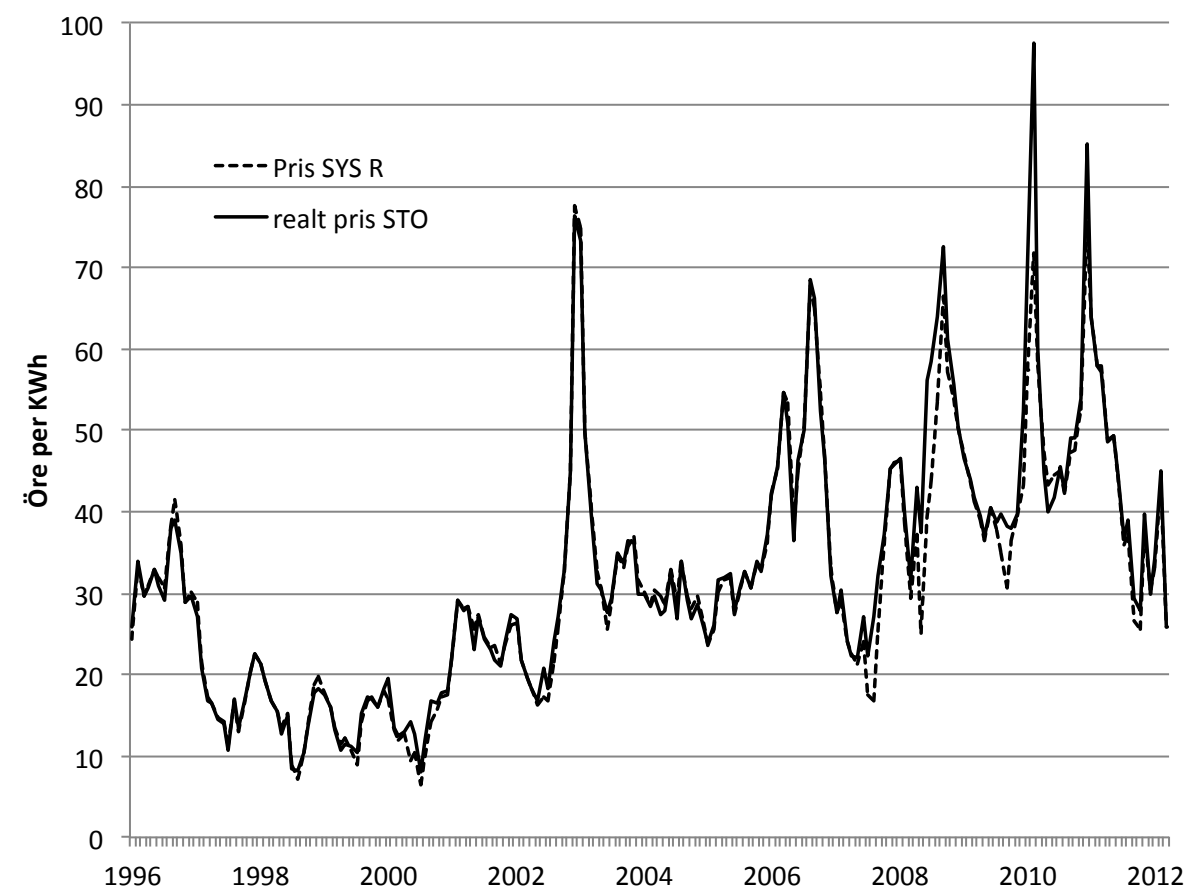

Figur 3.2: Månatligt genomsnittspris på el på Nordpool 1996-2012. Systempris (Pris SYS R) och prisområde Sverige (realt pris STO). Fasta priser, 2012 (mars) års penningvärde, öre per $\mathrm{kWh}$.

En första observation är att priset på el föll mellan 1996 och 2001. Efter 2001 steg priset och fram till 2006 kan man ana en positiv trend i priset, men efter det tycks det ha fluktuerat kraftigt runt 45 öre per KWh. En andra observation är att priset inte steg, utan snarare föll, de närmaste åren efter avregleringen 1996. En tredje observation är att variansen, eller fluktuationerna, i priset tycks ha ökat kraftigt under 2000-talet. Pristopparna under 2000-talet infaller under vintermånaderna. I februari 2010, exempelpris, var genomsnittspriset 93 öre per KWh, vilket ska jämföras med juni samma år då priset var 40 öre per KWh. Vintern 2011/2012 har varit relativt mild, vilket också återspeglas i priset med en pristopp på 45 öre i januari 2012. En fjärde observation är att variationen $\mathrm{i}$ 
pris är större inom det svenska prisområdet (realt pris STO) än systempriset på elbörsen. I februari 2010, exempelvis, ser vi att det är en signifikant prisskillnad mellan priset i Sverige och systempriset. Skillnaden kan förklaras att det inte fanns överföringskapacitet nog för att täcka den efterfrågeökning som skedde i Sverige. Generellt kan man säga att de perioder där det är en skillnad mellan de två priserna indikerar att det finns flaskhalsar i överföringskapacitet, priset mellan olika områden kan då helt enkelt inte jämnas ut. Vi återkommer i avsnitt 5 till en djupare analys av prisutvecklingen efter 1996.

Sammantaget visar prisutvecklingen inte på något entydig prisuppgång under perioden efter avregleringen 1996. Däremot tycks det vara så att variationen i priset ökat under 2000-talet. Som vi redan diskuterat indikerar det att de grundläggande funktionerna på marknaden fungerar på ett förväntat sätt, dvs. när tillgången och/eller efterfrågan ökar, då stiger priset och vice versa. Vi återkommer senare i rapporten till en mer djuplodande analys av detta.

I marknadsbeskrivningen ovan har vi antagit att marknaden fungerar som en perfekt konkurrensmarknad. En fråga som diskuterats och debatterats flitigt sedan avregleringen är om detta är en korrekt beskrivning av marknaden, eller om det snarare är så att vissa elproducenter har en dominerande ställning och därmed via sina produktionsbeslut kan påverka priset. Vi återkommer till frågan om marknadsmakt, men redan nu kan vi illustrera vad vi skulle förvänta oss vad gäller prisnivå och prisutveckling ifall en marknad karakteriseras av ofullständig konkurrens. Ofullständig konkurrens i form av marknadsmakt innebär såväl kortsiktiga som långsiktiga effekter. De kortsiktiga effekterna kommer sig av att vinsten av att öka produktionen i befintlig kapacitet motverkas av att det påverkar marknadspriset negativt. Den långsiktiga effekten blir en följd av att lönsamheten för nyinvesteringar i ökad produktionskapacitet minskar eftersom sådana investeringar pressar ned priset. Sammantaget innebär det att priset på el, på kort och lång sikt, på en ej fullständig konkurrensmarknad kommer att vara högre än vad det skulle vara på en konkurrensmarknad, vilket i sin tur innebär att elproduktionen blir lägre än vad som är samhällsekonomiskt effektivt. Ifall avregleringen 1996 innebar en marknadskoncentration skulle vi förvänta oss en nivåhöjning på priset, givet allt annat oförändrat. Prisutvecklingen som redovisas i figur 3.2 ger knappast stöd för ett sådant "prisskift". Det betyder dock inte att det inte skett ett sådant eftersom bilden som återges i figur 3.2 inte konstanthåller för alla andra faktorer som påverkar utbud och efterfrågan.

\section{Elmarknaden, en enkel numerisk analys}

I avsnitt 3 har vi gett en konceptuell bild av hur en avreglerad elmarknad skall fungera. I detta avsnitt skall vi använda oss av samt specificera denna konceptuella modell för att analysera möjliga effekter av olika scenarier vad gäller i första hand förändringar på tillförselsidan av elmarknaden. Den modell vi använder består av en utbuds- eller marginalkostnadskurva för det Nordiska elsystemet, samt en efterfrågekurva på det sätt som illustreras i figur 3.1. Kostnadsdata för de lika produktionsslagen avser rörliga kostnader i Europa (genomsnitt) för år 2007, och är tagna från Blesel m.fl. (2008). 
Kapaciteten för de olika kraftslagen är för det Nordiska produktionssystemet. Utbuds-,

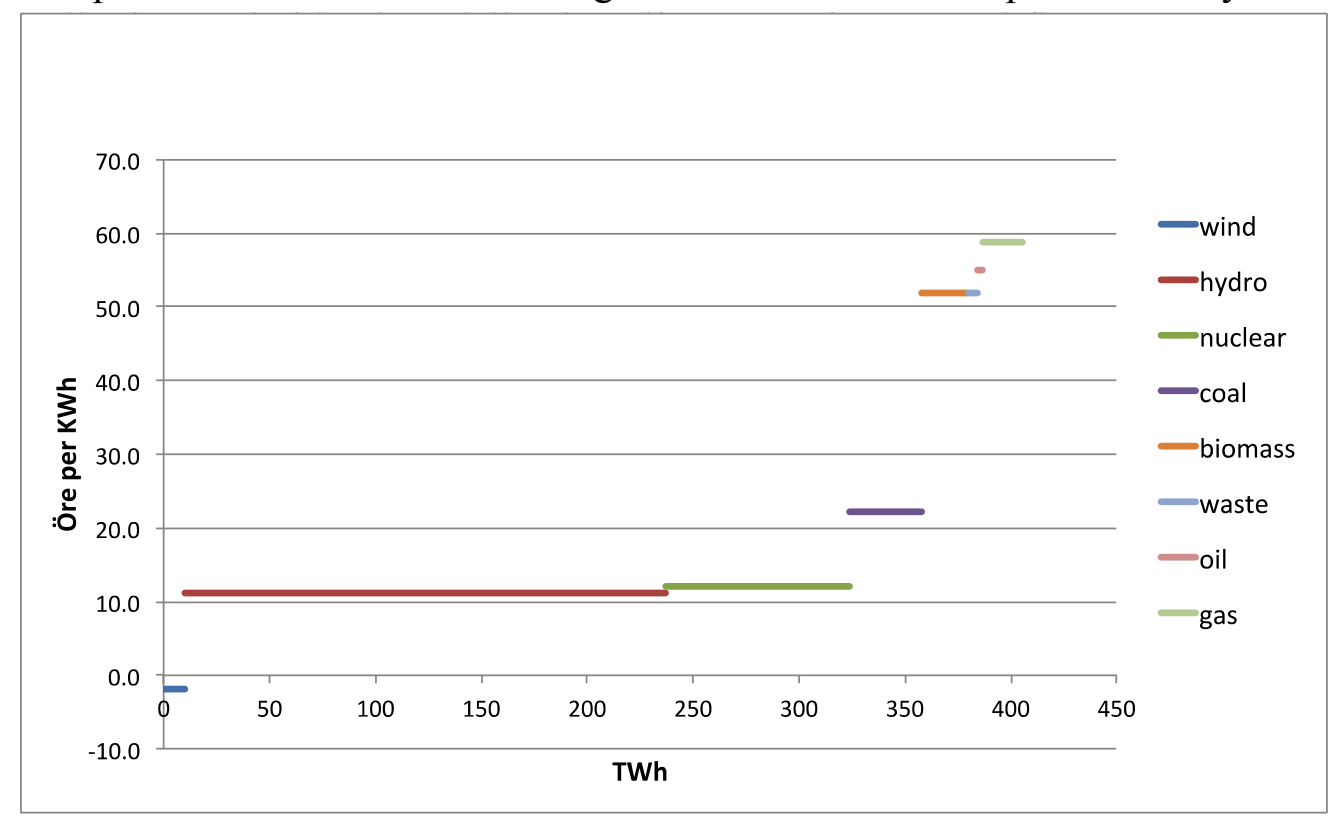

Figur 4.1: Rörliga kostnader för elproduktion (bränsle, drift och underhåll) och elproduktion i det Nordiska systemet. (Källa: Kostnadsdata är tagna från Blesel m.fl. (2008). Private Costs for Electricity and Heat Generation. Rapport från projektet "IEA and CASES - Cost Assessment for Sustainable Energy Markets". Project No 518294 SES6, Deliverable No D4.1. Produktionsdata är tagna från IEA (www.iea.org)).

I kostnaderna för vind och biomassa är värdet av elcertifikat bortdragna. Som vi kan se innebär det att den kortsiktiga marginalkostnaden för el från vindkraft är negativ. Bruttokostnaden för vindkraft, dvs. då vi inte beaktar elcertifikaten är cirka 25 öre per KWh. Efterfrågan i basfallet är kalibrerat så att jämviktspriset är lika med genomsnittspriset för 2010, dvs. 59 öre per KWh. Vi har antagit en linjär efterfrågefunktion med en priselasticitet på $-0.5 \mathrm{i}$ jämviktspunkten. Dessa antaganden vad gäller efterfrågan samt de data som redovisas i figur 4.1 ligger till grund för de beräkningar vi gör nedan. Givet dessa antaganden får vi ett referensfall som innebär en produktionsnivå på el som är drygt $380 \mathrm{TWh}$ i det nordiska systemet, vilket i sin tur ungefär motsvarar 2009 års produktionsnivå. Basfallet illustreras i figur 4.2. 


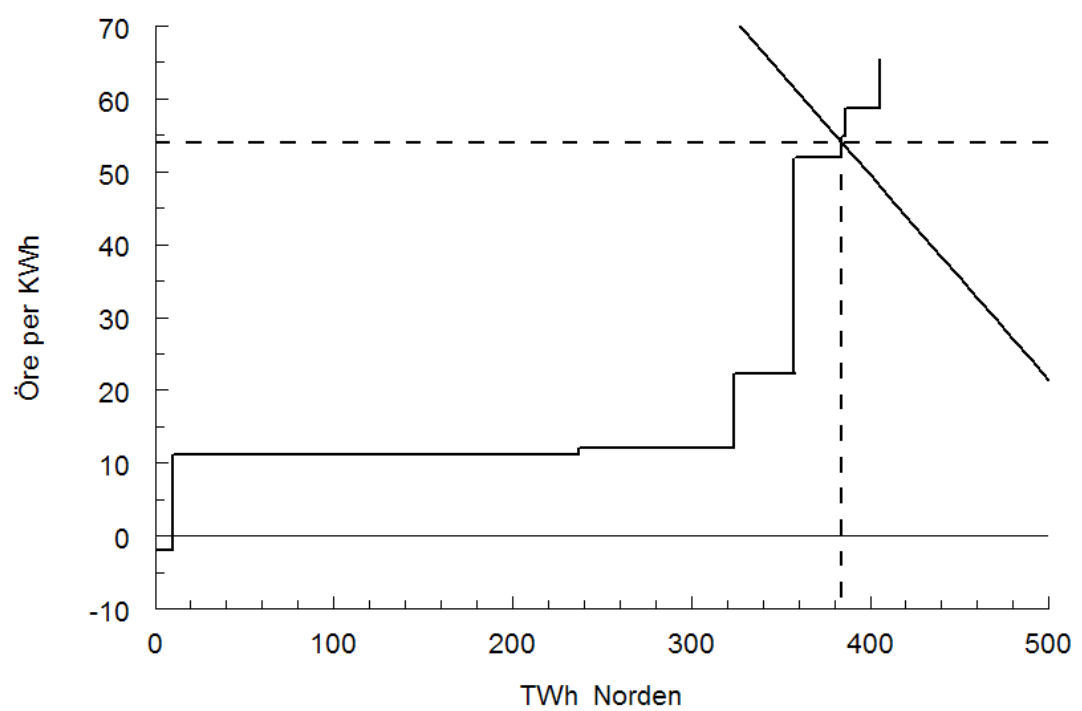

Figur 4.2: En numerisk modell av den nordiska elmarknaden (Källa: se figur 4.1).

Vi kan nu under de antaganden som gjorts relativt enkelt beräkna och illustrera effekterna av olika förändringar, såväl marknadsmässiga som politiska. Vi ska illustrera de möjliga effekterna av två olika förändringar vad gäller elmarknadens tillförselsida: (a) en avveckling av den svenska kärnkraften; samt (b) en utfasning av det svenska elcertifikatsystemet.

\subsection{Kärnkraften står stilla}

I det första experimentet antar vi att den svenska kärnkraften stängs av. Det betyder att produktionskapaciteten på el i det Nordiska systemet minskar från drygt $380 \mathrm{TWh}$ i basfallet till cirka $320 \mathrm{TWh}$. Den kärnkraftsproduktion som finns kvar i det nordiska systemet kommer således från Finland (ca 22 TWh). Den resulterande effekten på marknaden illustreras i figur 4.3.

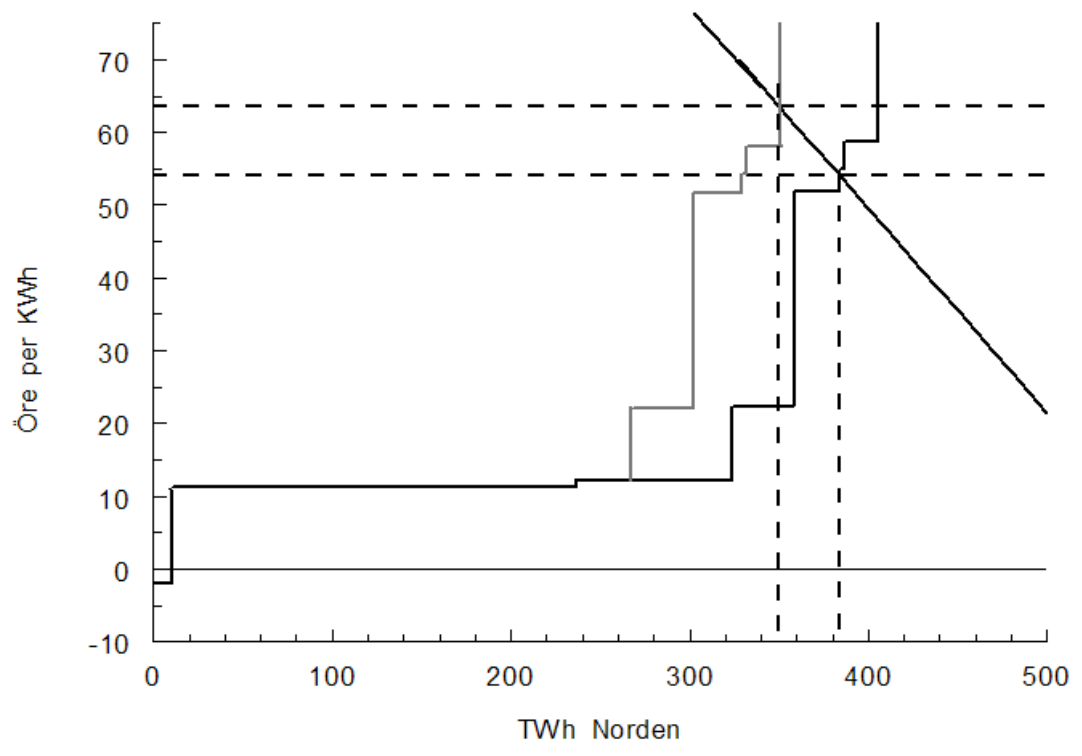

Figur 4.3: Marknadseffekter av att den svenska kärnkraften stängs av 
Som vi kan se skulle en stängning av den svenska kärnkraften leda till att det kortsiktiga priset på el stiger från 54 öre per KWh (årligt genomsnitt) till cirka 64 öre sett som ett genomsnitt över året. Vi ser också att produktionsminskningen inte blir fullt så stor som den initiala minskningen av kärnkraftsel. Skälet är att prisökningen leder till att dyrare produktionsslag tas i drift. I det nordiska systemet innebär det t.ex. att olja och naturgas kommer att användas i större utsträckning för att producera el.

Hur stor effekten på priset blir beror dels på priselasticiteten, dvs. hur känsliga konsumenterna är för prisförändringar, dels på efterfrågekurvans läge på utbudskurvan, dvs. om vi har ett läge med relativt hög eller relativt låg efterfrågan. Således kan vi förvänta oss att effekten på priset av stängning av kärnkraften blir högre under vintermånaderna än under sommarmånaderna. Vidare är det enkelt att se att om konsumenterna är mindre priskänsliga så blir priseffekten större. I tabell 4.1 redovisas effekterna på marknadspris och producentöverskott (vinster) i vattenkrafts- och kärnkraftsindustrin av en stängning av den svenska kärnkraften i enlighet med figur 4.3. Två alternativa beräkningar presenteras, en där vi antar att efterfrågans egenpriselasticitet (E) är -0.5 och en där denna elasticitet antas vara -0.1. Det senare fallet innebär således att konsumtionen är mycket okänslig för prisförändringar (i alla fall på kort sikt). En höjning av priset med tio procent innebär här att efterfrågan minskar med endast en procent.

Tabell 4.1: Effekter på pris och vinster (producentöverskott) på den nordiska elmarknaden av minskat utbud av el från svenska kärnkraftverk.

\begin{tabular}{|l|r|r|}
\hline Antagen priselasticitet & $\mathbf{E}=\mathbf{- 0 . 5}$ & $\mathbf{E}=\mathbf{- 0 . 1}$ \\
\hline P_0 (öre/KWh) & 54 & 54 \\
\hline P_1 (öre/KWh) & 64 & 97 \\
\hline Prisförändring (öre/KWh) & 10 & 43 \\
\hline Förändring i vinst vattenkraft, Norden (miljoner kr) & 21565 & 97610 \\
\hline Förändring i vinst vattenkraft, Sverige (miljoner kr) & 6574 & 29756 \\
\hline Förlust kärnkraft (miljoner kr) & 26199 & 26199 \\
\hline
\end{tabular}

Resultaten i tabell 4.1 visar att effekten på elpris, och därmed vinster, är relativt känslig för storleksordningen på efterfrågans egenpriselasticitet. Vi ser att om priselasticiteten antas vara -0.5 blir prisförändringen knappt 10 öre på kort sikt, vilket resulterar $\mathrm{i}$ att vinsterna från vattenkraften $\mathrm{i}$ det svenska systemet ökar med cirka 6.5 miljarder $\mathrm{kr}$ årligen. För hela det nordiska vattenkraftssystemet innebär det en vinstökning på mer än 21 miljarder kr. Förlusten från kärnkraften blir enligt denna beräkning 26 miljarder kr. Om priselasticiteten är -0.1 blir effekten på elpriset nästan fem gånger större, vilket naturligtvis innebär än större överskott från vattenkraften.

\subsection{Har elbolagen möjlighet samt incitament att utöva marknadsmakt?}

Sammantaget visar resultaten i tabell 4.1 att den förlust som uppstår vid en stängning av de svenska kärnkraftverken inte fullt ut kompenseras av de ökade vinsterna, dvs. ökat producentöverskott, från vattenkraften. Resultaten visar dock också att efterfrågans priselasticitet är en viktig parameter för storleken på vattenkraftens vinster. Även om våra 
resultat inte explicit visar på förekomsten av marknadsmakt kan det inte uteslutas att detta är ett reellt problem på den nordiska elmarknaden. Om elbolagen är få och dessutom äger såväl vattenkraft som kärnkraft kan de ha ett incitament att begränsa produktionen och därmed öka intäkterna för den produktion som fortfarande är $\mathrm{i}$ drift. På vattenkraftssidan kan det också finnas en möjlighet att skifta produktionen från en tidsperiod till en annan för att utnyttja variationer i storleken på elefterfrågans priselasticitet (i den mån det går att uppskatta dessa variationer). Eftersom frågan om marknadsmakt inte undersöks explicit i denna rapport är det relevant att kort konsultera resultaten från tidigare studier som undersökt detta i mer detalj.

Elmarknaden har generellt sett många av de egenskaper som gör att utövandet av marknadsmakt kan vara ett potentiellt problem (t.ex. relativt få och stora företag, höga inträdesbarriärer, låg priskänslighet i efterfrågan, flaskhalsar i överföringskapaciteten mellan olika geografiska regioner etc.). En rad empiriska studier som undersökt förekomsten av kortsiktig marknadsmakt, dvs. möjligheterna för producenterna driva upp priset genom att begränsa produktionen i existerande anläggningar. ${ }^{9}$ Ett sätt att undersöka denna fråga är att med hjälp av en simuleringsmodell som antar fullständig konkurrens (liknande den som presenteras ovan), jämföra det prisutfall (marginalkostnad) som modellen genererar med det pris som vi kan observera på t.ex. Nordpool. Sådana modellsimuleringar visar generellt sett att de skattade marginalkostnaderna är väl i paritet med de faktiska priserna på spotmarknaden samt att de avvikelser som finns är svåra att härleda till utövandet av marknadsmakt. ${ }^{10}$ Det finns också ett antal ekonometriska studier där man statistiskt testar för om det finns en så kallad "mark-up" på marginalkostnaden. Den slutsats man kan dra från dessa studier är att det inte tycks finnas en sådan "markup", eller att den är mycket liten och dessutom har minskat över tiden efter avregleringen. ${ }^{11}$ Överlag finns således ringa stöd för att de nordiska elproducenterna utnyttjar sin storlek och pressar upp priset på el.

Vissa undersökningar indikerar dock att elbolagen ibland har möjlighet att utnyttja flaskhalsar i överföringskapaciteten för att utöva marknadsmakt lokalt. Exempelvis skulle en elmarknad som enbart omfattar Sverige kunna ge de största företagen (med höga produktionsandelar) en möjlighet att påverka priset till ineffektiva (och för höga) nivåer. ${ }^{12}$ Erfarenheten från den nordiska elmarknaden är dock att Sverige har varit en del av ett tillräckligt stort prisområde för att de svenska producenterna ska känna av en

\footnotetext{
${ }^{9}$ Se bl.a. Amundsen, E. S., och L. Bergman (2006). "Why has the Nordic Electricity Market Worked so Well?" Utilities Policy, Vol. 14, s. 148-157; samt även Damsgaard, N., och R. Green (2005). Den nya elmarknaden. Framgång eller misslyckande? SNS förlag, Stockholm.

${ }^{10}$ En genomgång samt en kritisk granskning av sådana simuleringsstudier återfinns i Fridolfsson, S-O, och T. P. Tangerås (2009). "Fungerar konkurrensen på elmarknaden?" Ekonomisk Debatt, Vol. 37, Nr. 8, s. 21-37.

${ }^{11}$ Med hjälp av månadsdata från 1996 till 2007 finner Bask m.fl. (2011) en positiv "mark-up" på priset, men att den minskat över tiden. Enligt deras beräkningar skulle denna "mark-up" implicera en avvikelse från konkurrenspriset med mindre än 1 procent.

${ }^{12}$ En tidig studie som visar detta är Andersson, B., och. L. Bergman (1995). "Market Structure and the Price of Electricity: An Ex Ante Analysis of the Deregulated Swedish Electricity Market," The Energy Journal, Vol. 16, Nr. 2, s. 97-109.
} 
omfattande priskonkurrens. Under de relativt få timmar som Sverige är en del mycket mer koncentrerad marknad kan dock problem med marknadsmakt finnas.

Diskussionen så här långt har rört de eventuella problemen med marknadsmakt då elbolagen planerar sin produktion givet sin kapacitet. Det kan dock även finnas en möjlighet för företagen att utöva marknadsmakt i sina investeringsbeslut; om inträdesbarriärerna för nya företag är höga kan det vara lönsamt för de existerande elbolagen att undvika (eller skjuta på) investeringar för att på så sätt hålla uppe priset. Denna aspekt på marknadsmakt har inte belysts empiriskt på den nordiska elmarknaden. I en relativt ny studie från Expertgruppen för miljöstudier diskuteras dock de eventuella problemen med långsiktig marknadsmakt. ${ }^{13}$ Författarna argumenterar för att detta problem inte ska negligeras på den nordiska elmarknaden. Det finns en rad etableringshinder, ofta av politisk karaktär och inte minst kopplat till den svenska kärnkraften. Den nuvarande politiska linjen är att endast de nuvarande elbolagen får äga ny kärnkraft. I kombination med det samägande av kärnkraften som finns i Sverige går det inte att utesluta att producenterna kommer att ta hänsyn till priseffekten i sina investeringsbeslut (och därmed underinvestera i ny kärnkraft). I rapporten föreslås därför ett anbudsförfarande där alla intresserade bolag (även utländska) konkurrerar om att få bygga samt driva nya kärnkraftverk i Sverige.

Såsom påpekats ovan undersöker vi inte denna problematik explicit i denna rapport. Det bör dock noteras att våra ekonometriska analyser (se avsnitt 5) visar tydligt att faktorer som på olika sätt fördyrar tillförseln av el får ett tydligt genomslag på elpriset på den nordiska elmarknaden. Detta bekräftar empiriskt de simuleringsresultat som presenteras ovan (tabell 4.1). Det visar också att en viktig strategi för att åstadkomma effektiva elpriser är att inte på ett omotiverat sätt begränsa investeringar i ny kapacitet. Därför finns anledning att även fortsättningsvis följa upp de eventuella problemen med samägande och korsägande samt även de som rör tillståndsprövningen av nya anläggningar. ${ }^{14}$

\subsection{Elcertifikat och förnyelsebar elproduktion}

I det andra modellexperimentet analyserar vi effekterna av de svenska elcertifikaten och infasningen av förnyelsebar el. Elcertifikatssystemet infördes 2003 i syfte att öka andelen förnyelsebar el i det svenska elsystemet. Basen i systemet är kvotplikten som anger att en given andel av den el som används måste komma från förnyelsebara energikällor som t.ex. sol, vind, ny vattenkraft och bioenergi. Kvotplikten är för närvarande $17 \%$. Marknaden för elcertifikat fungerar som så att en producent av förnyelsebar el tilldelas ett certifikat för varje MWh denne producerar. Certifikaten säljs till elleverantörerna som ansvarar för att användarna uppfyller kvotplikten; leverantörerna har rätt att ta ut en ersättning för att hantera kvotplikten via elräkningen. Priset på elcertifikat kommer därmed att bestämmas av i grunden tre faktorer: (a) kostnaden för att producera förnyelsebar el; (b) elefterfrågan; samt (c) nivån på kvotplikten. Blir

\footnotetext{
${ }^{13}$ Fridolfsson, S-O., och T. P. Tangerås (2011). Investeringar på elmarknaden-fyra förslag för förbättrad funktion, Rapport till Expertgruppen för miljöstudier 2011:5, Finansdepartementet, Stockholm.

${ }^{14}$ Se t.ex. Pettersson, M., och P. Söderholm (2011). "Reforming Wind Power Planning and Policy: Experiences from the Nordic Countries," CESifo DICE Report: Journal for Institutional Comparisons, Nr. 4, s. 54-60.
} 
det billigare att producera förnyelsebar el faller priset på elcertifikaten, och ökar elefterfrågan eller om en högre kvot krävs så kommer priset på certifikat att öka.

Priset på certifikat har sedan starten 2003 pendlat mellan 15 och 30 öre per kWh. Det betyder i praktiken att producenter av exempelvis vindel erhåller en subvention på mellan 15 och 30 öre per KWh. För elkonsumenterna innebär systemet att minst $17 \%$ av den el man använder är förnyelsebar el, och att man får betala för det. Den direkta effekten för konsumenten blir därmed kvotplikten (17\%) multiplicerat med priset på certifikat. Antag exempelvis att priset på certifikat är 25 öre per KWh. Då blir den direkta effekten på konsumentens elräkning $25 * 0,17=4,25$ öre plus moms.

Elcertifikatssystemet har även en indirekt effekt på elmarknaden eftersom systemet kan innebära att helt ny produktionskapacitet tillförs marknaden, vilket leder till att dyrare energislag trycks ut från marknaden och att marknadspriset därmed blir lägre. Hur stor den effekten är beror på ett antal faktorer. Om elcertifikaten innebär att el som annars inte skulle ha producerats nu produceras så blir effekten att dyrare el trycks ut, och att priset på marknaden därmed faller. Om, å andra sidan, elcertifikaten innebär att el som redan är lönsam att producera erhåller certifikat får vi inga kortsiktiga effekter på marknaden, och därmed inga priseffekter. Dock blir investeringar i förnyelsebar än mer lönsamma, vilket trycker undan dyrare icke-förnyelsebar el, vilket pressar ned priset. Hur stor priseffekten blir beror, återigen, på efterfrågeläget, produktionskostnaden för den el som trycks ut och priset på elcertifikat (och därmed också på kostnaderna för att producera förnyelsebart och nivån på kvotplikten). En prispress nedåt på grund av detta betyder dock inte nödvändigtvis att det pris konsumenten får betala blir lägre eftersom det är konsumenten som i slutändan betalar för den ytterligare produktionen av förnyelsebar el. Var denna produktion i utgångsläget mer kostsam än den el som trycks undan med certifikaten blir nettoeffekten för konsumenten en prishöjning.

I figur 4.1 och 4.2 ovan ser vi att el producerad med vindkraft har en negativ marginalkostnad efter det att intäkten från elcertifikat är bortdragen. Det betyder att befintlig vindkraft är lönsam även utan elcertifikat. För biomassa ser vi att bilden är något annorlunda. Ett marknadspris lägre än 52 öre per KWh innebär att el från biomassa (om man inte kan sälja värmen till marknadspris) inte är lönsam ens på kort sikt utan subventionen från certifikaten. Det betyder att i avsaknad av elcertifikaten skulle i alla fall en andel av elproduktionen från biomassa ersättas med el från gas och olja (åtminstone periodvis).

Vi kan nu göra en liknande beräkning som i kärnkraftsfallet. Om vi antar att elcertifikatsystemet (och därmed kvotplikten) tas bort innebär det att den svenska vindkraften och den svenska elkraften från biomassa inte längre bidrar till elproduktionen. Då får vi en ungefärlig minskning av produktionskapaciteten med $11 \mathrm{TWh}$. Givet de antagande vi gjort om efterfrågans priselasticitet $(-0.5)$ så blir effekten på priset av elcertifikaten cirka 2 öre per $\mathrm{kWh}$. Med andra ord bidrar subventionen till att pressa ned marknadspriset eftersom produktion som annars inte skulle ske nu sker. Som redan påpekats betyder det inte att elkonsumenterna får lägre kostnad för el eftersom den kraft som tidigare var för dyr för att produceras nu måste betalas via elcertifikatmarknaden. 
Det bör noteras att våra simuleringar bygger på att de produktionsslag som existerar på den nordiska elmarknaden endast skiljer sig åt vad gäller de rörliga kostnaderna. I praktiken är dock bilden mycket mer komplicerad. Vindkraften, som utgör en viktig del av elcertifikatsystem, är instabil och kommer därför att påverka volatiliteten i elpriset. Detta påverkar i sin tur de ekonomiska förutsättningarna för investeringar i annan elkraft, och det är långt ifrån självklart hur den långsiktiga jämvikten påverkas av ett ökat inslag av vindkraft. Det är dock sannolikt att flexibla teknologier (t.ex. vattenkraft) samt teknologier med låga kapitalkostnader (t.ex. naturgas) gynnas eftersom dessa inte kommer att utnyttjas då det blåser mycket. ${ }^{15}$

Effekterna av vindkraftens introduktion på prisvolatiliteten samt det långsiktiga elpriset på den nordiska elmarknaden har inte undersökts i detalj. I en studie visas dock att den danska vindkraften har stabiliserat prissvängningarna över dagen, men medfört ökad prisvolatilitet på längre sikt. ${ }^{16}$ En intressant implikation av detta är att den utjämning av priset som sker på daglig basis kan leda till en reducerad lönsamhet för investeringar i reservkapacitet, men denna reduktion kan leda till ökad stress på elsystemet då det råkar blåsa litet under höglastperioder.

Sammanfattningsvis har det främsta syftet med detta avsnitt varit att på ett enkelt sätt illustrera och analysera effekter på elmarknaden av olika förändringar på marknaden. Ett grundläggande antagande $i$ analysen har varit att marknaden fungerar på det sätt som konkurrensmarknader antas fungera, dvs. att pris och kvantitet på marknaden bestäms av utbud och efterfrågan och därmed av kostnader för att producera el samt konsumenternas betalningsvilja. I nästa avsnitt utnyttjar vi data över den faktiska utvecklingen på den nordiska elmarknaden, och analyserar elpriset med hjälp av olika ekonometriska metoder. Detta ger oss en möjlighet att belysa om ovanstående enkla modell erbjuder en rimlig beskrivning av hur marknaden fungerar samt ytterligare belysa vilka faktorer som varit avgörande för de ökade elpriserna under de senaste 10-15 åren.

\section{Ekonometriska analyser av elprisutvecklingen}

Syftet med detta avsnitt är att utifrån verkliga data empiriskt analysera elprisets bestämningsfaktorer. Av speciellt intresse är att studera om avregleringen 1996 har haft någon påverkan, positiv eller negativ, på priset. I den första delen kommer vi att undersöka om avregleringen haft någon betydande effekt på elpriset, och vilken påverkan fundamentala variabler som styr efterfrågan och utbud har haft på elpriset sett över en längre tidsperiod. Här använder vi årliga data för perioden 1970 till 2010, och elpriset avser det rörliga priset för en hushållskund. I den andra delen analyserar vi utvecklingen efter 1996 med hjälp av månadsdata, och med elpris här avser vi det genomsnittliga månadspriset på Nordpool.

\footnotetext{
${ }^{15}$ Se t.ex. Green, R., och N. Vasilakos (2011). The Long-Term Impact of Wind Power on Electricity Prices and Generating Capacity, Department of Economics Discussion Paper 11-09, University of Birmingham.

${ }^{16}$ Mauritzen, J. (2010). What Happens when it's Windy in Denmark? An Empirical Analysis of Wind Power on Price Volatility in the Nordic Electricity Market, Discussion Paper, Norwegian School of Economics and Business Administration.
} 


\subsection{Tidigare studier och angreppssätt}

I kapitel 2 presenterades samt kommenterades elprisutvecklingen i Sverige och Norden under perioden 1970-2010. Denna utveckling visar på en tydlig uppåtgående trend $\mathrm{i}$ prisnivåerna under de senaste tio åren, men det är fel att enbart utifrån denna observation dra slutsatsen att avregleringen 1996 haft en prishöjande effekt. En analys av avregleringens effekter måste kontrollera för de andra faktorer (t.ex. bränslepriser, efterfrågeutveckling etc.) som påverkat elpriset under denna period. Den relevanta jämförelsen är att vid en given tidpunkt ställa den prisnivå som gäller under konkurrensutsatta förhållanden mot motsvarande prisnivå under en reglerad marknadsstruktur.

Ett vanligt angreppsätt i tidigare studier är att utgå från en reducerad regressionsmodell där elpriset antas vara en funktion av en rad exogena variabler som påverkar efterfrågan och utbud av el. ${ }^{17}$ Dessutom inkluderas en enkel diskret s.k. dummyvariabel (0/1), som kan användas för att testa nollhypotesen att avregleringen (allt annat lika) inte haft någon effekt på elpriset. Denna metod är enkel och väl grundad i ekonomisk teori. En prisekvation i s.k. reducerad form härleds från en enkel jämviktsmodell där utbudet antas vara lika med efterfrågan på marknaden. Det betyder att priset i vår modell blir en funktion av några av de viktigaste faktorer som påverkar efterfrågan och utbud på den nordiska elmarknaden. Trots sin enkelhet innebär denna metod samtidigt viktiga metodologiska utmaningar som vi måste förhålla oss till.

Det är bl.a. inte självklart hur avregleringen ska definieras och operationaliseras. Ett skäl till det är att effekterna av en avreglering kan skönjas redan innan den genomförs formellt $\mathrm{i}$ och med att företagen känner till förändringen och därmed anpassar sitt beteende redan innan den är implementerad. Det kan dessutom ta några år innan effekterna av avregleringen fått fullt genomslag på marknaden. I vår analys testar vi därför två olika variabler för att testa för en avregleringseffekt. Först utnyttjar vi en traditionell diskret dummyvariabel, som är lika med noll (0) under perioden före 1996 och som därefter är lika med ett (1). Vi testar även en s.k. logistisk dummyvariabel som utgår från att avregleringen införs gradvis, ${ }^{18}$ den antas inledas 1994 och är fullt implementerad först 1998.

Den prisnivå som observeras efter avregleringen kan vara missvisande. Ett skäl till det är att under den reglerade perioden kunde företagen ibland ofta utan betydande risk investera i ny produktionskapacitet. Detta innebär att när marknaden avregleras finns överkapacitet $\mathrm{i}$ elsystemet och det leder till lägre priser under en period efter avregleringen. I vår modell tar vi inte explicit hänsyn till eventuell överkapacitet under perioden efter 1996. Vår bedömning är att denna effekt bör vara relativt liten på den

\footnotetext{
${ }^{17}$ Se t.ex. surveyartikeln av Kwoka, J. (2008). "Restructuring the U.S. Electric Power Sector: A Review of Recent Studies," Review of Industrial Organization, Vol. 32, pp. 165-196. Se även Joskow, P. L. (2006). "Markets for Power in the United States: An Interim Assessment," The Energy Journal, Vol. 27, No. 1, pp. 1-36, and Taber, J., D. Chapman, and T. Mount (2006). Examining the Effects of Deregulation on Retail Electricity Prices, Working Paper WP 200514, Department of Applied Economics and Management, Cornell University, USA.

${ }^{18}$ Denna variabelspecifikation bygger på Thiel, J. E. och van Giersbergen, N. P. A. (2010). The Effect of European Integration on Exchange Rate Dependence: The Polish Accession to the EU, Discussion Paper 2010/10, Amsterdam School of Economics.
} 
svenska marknaden. Såsom påpekats ovan (se avsnitt 2.1) var prissättningen på producentmarknaden relativt sett effektiv under den reglerade perioden; under perioder då kapaciteten byggdes ut sjönk också producentpriserna vilket gjorde ytterligare ny kapacitet mindre lönsam. ${ }^{19}$

Det är ibland dessutom svårt att på solid grund hävda att avregleringen faktiskt orsakat en förändring i priserna (och således inte endast råkar samvariera med prisnivån). Såsom påpekats ovan är det därför viktigt att bl.a. kontrollera för de andra variabler som påverkar elpriset, och beroende på analysens inriktning kan effekterna av selektion och endogenitet också behöva uppmärksammas. ${ }^{20}$

Utgångspunkten för analysen är data från Svensk Energi över det årliga reala elpriset för en hushållskund med rörligt kontrakt under perioden 1970-2010 (uttryckt i öre per kWh i 2010 års prisnivå). Vi inkluderar moms samt punktskatt på el i analysen av konsumentprisets utveckling. Dessa är viktiga att ha med eftersom höjningar av dessa skatter har bidragit till hushållens högre elräkningar under de senaste 20 åren. En annan viktig anledning till att inkludera dessa är att de påverkar jämviktsförhållandena på elmarknaden, och därför också den reducerade formen för prisekvationen. Eftersom momsen är uttryckt som en procentandel av priset är den absoluta effekten på elpriset endogent bestämt, vilket komplicerar analysen betydligt (och gör den reducerade formen ickelinjär). I analysen nedan specificerar vi en reducerad form där dessa skatter ingår men göra några antaganden som förenklar analysen. Effekterna av EU ETS samt elcertifikatsystemet finns också med i de prisserier som analyseras.

Denna elprisserie utnyttjas i två steg. I ett första steg genomför vi ett test för stationäritet och strukturella brott i tidsserien; denna analys ger en första (preliminär) indikation om det finns skäl att misstänka att avregleringen inneburit ett tydligt "brott" i prisutvecklingen eller om det snarare är andra faktorer som varit viktigare för att förstå denna utveckling. I ett andra steg specificeras en reducerad regressionsmodell där det årliga elpriset antas vara en funktion av en rad olika utbuds- och efterfrågepåverkande faktorer samt av ett dummyvariabel för avregleringen (se ovan). Denna del av analysen belyser dels vilken effekt (om någon) avregleringen kan ha haft på elpriset men även hur en rad andra faktorer påverkat prisutvecklingen.

\subsection{Förekomsten av strukturella brott i elpriset}

I detta avsnitt använder vi en metod för att testa för förekomsten av stationäritet och strukturella brott i tidsserien över elpriset. En variabel är stationär om dess medelvärde och varians är konstanta över tiden. Metoden bygger på att eventuella strukturella brott

\footnotetext{
${ }^{19}$ Bergman, L. T. Hartman, L. Hjalmarsson, och S. Lundgren (1994). Den nya elmarknaden, SNS förlag, Stockholm.

${ }^{20}$ Selektion och endogenitet är kanske främst ett problem i studier som utnyttjar paneldata, dvs. en kombination av tidsserier samt observationer från flera länder eller regioner. Många amerikanska studier (t.ex. Joskow, 2006) utnyttjar t.ex. den variation i elmarknadsreglering som finns mellan stater i USA i kombination med prisutvecklingen över tid. Selektions- och endogenitetsproblemet består här av att de stater som avreglerat sina marknader inte nödvändigtvis utgör ett slumpmässigt urval utan de kanske valt att avreglera just på grund av att elpriserna initialt var höga. Vår analys bygger helt på en enskild tidsserie för Sverige.
} 
identifieras endogent och den fångar upp gradvisa (inkrementella) förändringar i medelvärdet. ${ }^{21}$ Maximalt två brott i tidsserien kan detekteras med denna metod. Analysen ger inga svar på vilka underliggande faktorer som kan förklara de strukturella brott som identifieras, men i avsnittet diskuterar vi möjliga förklaringar som sedan undersöks i mer detalj i avsnitt 5.3.

Figur 5.1 visar resultaten av detta test då vi använt elpriset exklusive moms och punktskatter på el. Den övre delen av Figur 5.1 visar att metoden då identifierar två strukturella brott i tidsserien, 2001 samt 2006. En viktig anledning till "brottet" 2006 kan vara införandet av EU ETS 2005, som medfört ett högre pris på kol i det nordiska elsystemet och detta "spiller över" på elpriset i Norden. Tidigare studier bekräftar detta samband, och indikerar att en betydande del av de högre bränslekostnaderna får betalas av nordiska elkonsumenter. ${ }^{22}$ I den nedre delen har vi tagit bort effekten av EU ETS på elpriset och då detekterar metoden i stället 1986 som ett viktigt strukturellt brott. Detta resultat är således i linje med vår slutsats ovan om EU ETS betydelse. Den prissänkande effekten som kan skönjas efter 1986 kan kopplas till att 1985 var den svenska kärnkraften färdigutbyggd och vi fick en period av lägre priser (ibland refererat till som "elrea"). ${ }^{23}$

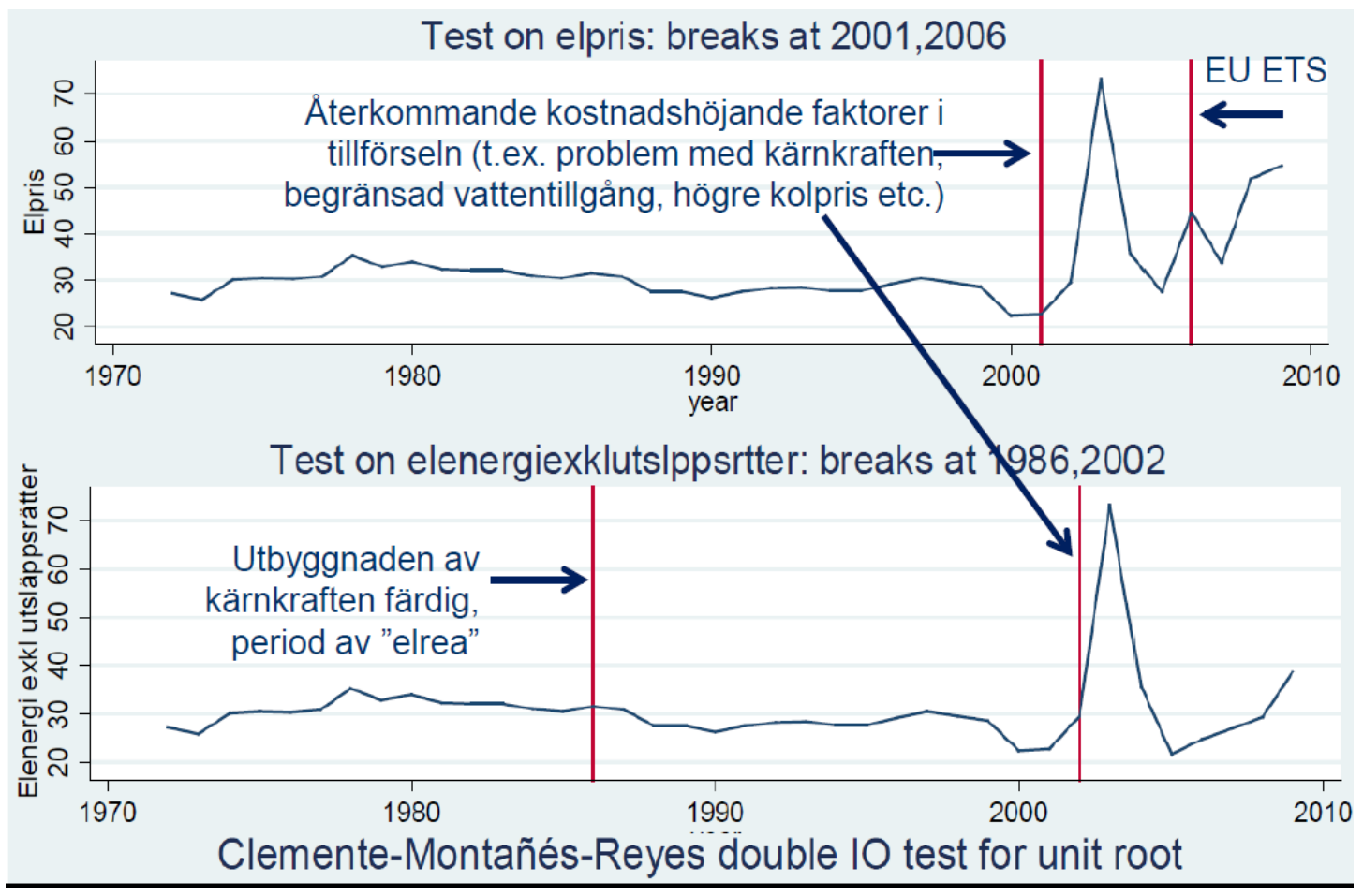

Figur 5.1: Test för strukturella brott: elpriset exklusive moms och punktskatter

\footnotetext{
${ }^{21}$ Se Clemente, J., A. Montanes, och M. Reyes (1998). "Testing for Unit Root in Variables with a Double-change in the Mean," Economics Letters, Vol. 59, s. 175-182.

${ }^{22}$ Se t.ex. Fell, H. (2010). "EU ETS and Nordic Electricity: A CVAR Analysis," The Energy Journal, Vol. 31, Nr. 2, s. 1-25.

${ }^{23}$ Bergman, L. T. Hartman, L. Hjalmarsson, och S. Lundgren (1994). Den nya elmarknaden, SNS förlag, Stockholm.
} 
De strukturella brott som identifieras för 2001 respektive 2002 är svårare att koppla till en enskild händelseutveckling. En möjlig tolkning är att detta "brott" fångar upp effekterna av en fördröjd avregleringseffekt, dvs. att priserna hölls nere efter 1996 på grund av överkapacitet men sedan steg som ett resultat av avregleringen (t.ex. kopplat till utövningen av marknadsmakt och begränsad konkurrens). Vår bedömning är dock att denna tolkning inte stämmer väl överens med verkligheten; dels är det (såsom påpekats ovan) inte sannolikt att det fanns en betydande överkapacitet i Sverige vid tiden för avregleringen och dels pekar tidigare studier på att det finns lite evidens för att konkurrensen på den nordiska elmarknaden skulle vara begränsad på grund av utövandet av marknadsmakt (se avsnitt 4.2). ${ }^{24}$

En rimligare tolkning är att sedan början av 2000-talet har en rad händelser lett till högre kostnader för eltillförseln generellt i Norden. Dessa inkluderar högre kolpriser, en mindre tillgänglig kärnkraft (inklusive nedläggning av reaktorer), samt en begränsad vattentillgång under vissa perioder (se vidare avsnitt 5.3). I Sverige har också införandet av elcertifikat 2003 medfört högre konsumentpriser. Motsvarande test för strukturella brott för de andra nordiska länderna (t.ex. Danmark och Norge) bekräftar resultatet rörande ett strukturellt brott under åren strax efter milleniumskiftet, något som också talar emot tolkningen av detta brott som en fördröjd svensk avregleringseffekt.

Figur 5.2 visar resultaten då vi i elpriset även inkluderat moms samt punktskatter på el. Även här detekterar metoden ett strukturellt brott 2001, och tolkningen är densamma som ovan. De ökade kostnaderna för tillförseln av el får bäras av konsumenterna i form av ökande priser. Det andra strukturella brottet identifieras vid år 1991. Detta är det år då moms på el infördes och efter 1991 har även elskatten gradvis höjts. Den mest rimliga tolkningen är därför att detta brott bör hänföras till dessa skattehöjningar. Fortsättningsvis i detta kapitel bortser vi från effekterna av moms och punktskatter på elpriset.

Sammantaget kan man säga att de som redovisas i figur 5.1 och 5.2 ger något stöd för att avregleringen 1996 skulle ha lett till några strukturella brott i prisutvecklingen.

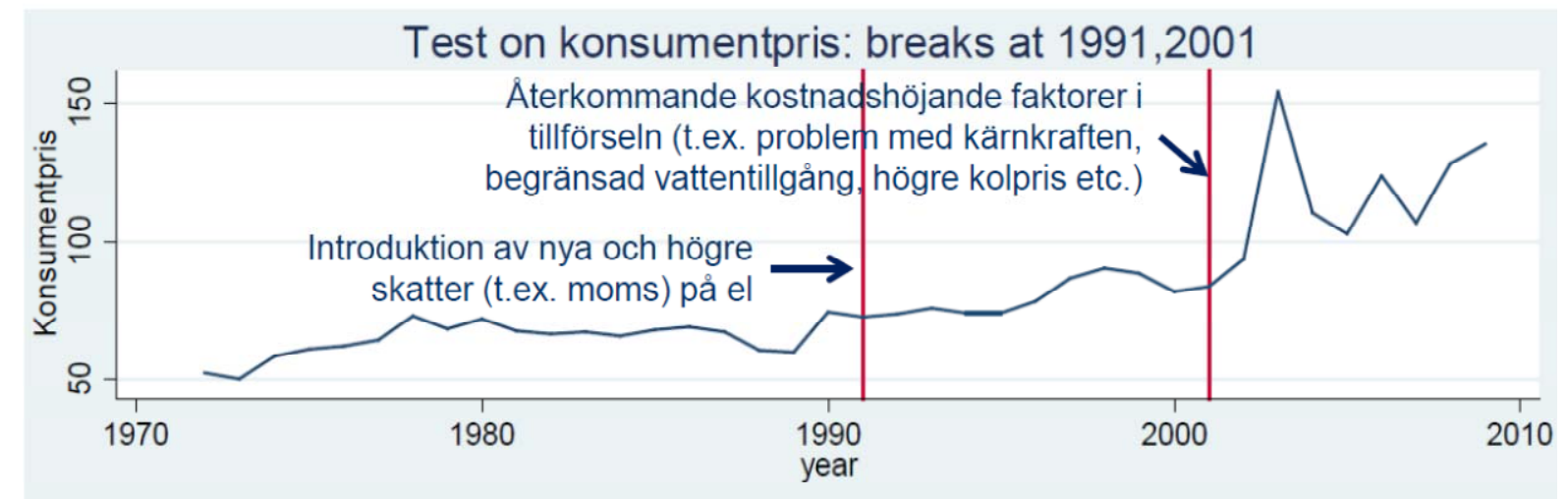

Figur 5.2: Test för strukturella brott: elpriset inklusive moms och punktskatter

\footnotetext{
${ }^{24}$ Under den reglerade perioden kunde de existerande företagen samarbeta och således begränsa tillträdet till marknaden.
} 


\subsection{En ekonometrisk analys av elprisets utveckling under perioden 1970-2010}

I detta avsnitt redovisas resultaten av den reducerade prismodell som introducerades kort i avsnitt 5.1. Dels skattar vi en reducerad form där den beroende variabeln är det pris på el som konsumenten möter, dvs. inklusive skatter, men även en modell där punktskatter och moms inte inkluderas. Mer specifikt specificerar vi en loglinjär regressionsmodell enligt följande:

$\ln$ elpris $=\alpha_{1}+\alpha_{2} \ln$ kolpris $+\alpha_{3} \ln$ kärnkraft $+\alpha_{4} \ln$ temperatur + $\alpha_{5} \ln$ nederbörd $+\alpha_{6} \ln B N P+\alpha_{7} \ln$ avreglering $+\alpha_{7} \ln s k a t t+\varepsilon$

Data över kolprisets utveckling är hämtat från International Energy Agency's databas, medan årsnederbörds- och temperaturdata kommer från SMHI. Eftersom nederbörden under föregående år $(t-1)$ kan påverka elpriset nuvarande år $(t)$ tar vi även hänsyn till ett laggat värde på denna. Kärnkraftens tillgänglighet approximeras med produktionen $\mathrm{i}$ TWh, och BNP finns med för att fånga upp effekterna på elpriset av en växande ekonomi. Såväl BNP som temperaturvariabeln fångar upp skift i efterfrågan; när temperaturen är låg (och behovet av uppvärmning ökar) samt BNP är högt ökar efterfrågan på el, och vi skulle förvänta oss ett (allt annat lika) högre elpris. Årliga förändringar i kolpriset, årsnederbörden samt kärnkrafts-produktionen innebär att kostnaderna för eltillförseln påverkas; en ökning i kolpriset innebär allt annat lika ett högre kolpris medan högre nederbördsnivåer samt ökad kärnkraftsproduktion bör föra med sig lägre priser. I den skattevariabel som inkluderas ingår punktskatten på el, elcertifikatavgiften, och dessa multiplicerade med momsen (se tabell 5.1). Inledningsvis antar vi att skattenivåerna är exogent givna, vilket (som antytts ovan) är en förenkling. $\varepsilon$ är en slumpterm, och den fångar upp den del av prisvariationen som inte kan förklaras av de i modellen ingående variablerna. Användandet av en loglinjär funktionsform innebär att de skattade koefficienterna kan tolkas som enhetsoberoende elasticiteter.

Såsom påpekats ovan testar vi två olika dummyvariabler för att fånga upp effekterna av avregleringen, och resultaten från båda dessa specifikationer redovisas nedan. För att kontrollera robustheten i resultaten testas också en rad andra specifikationer, bl.a. en där tidsperioden begränsas till 1980-2010 samt en där funktionsformen antas vara linjär.

Tabell 5.1 visar de skattade koefficienterna i grundmodellen (ekvation 5.1) med och utan skatt, samt där avregleringens effekter operationaliserats på två olika sätt.

Överlag bekräftar resultaten bilden av en marknadsstruktur där viktiga exogena förändringar i utbuds- och efterfrågepåverkande faktorer har ett tydligt genomslag på elpriset. Förklaringsgraden (R2-värdet) är överlag hög. Nästan alla koefficienter är statistiskt signifikanta och har förväntat tecken. Högre kolpris och/eller högre BNP leder allt annat lika till ett högre elpris, medan högre nederbörd, högre temperatur, samt en högre kärnkraftsproduktion leder till ett lägre pris. Analysen visar också att skattehöjningar på el har en betydande effekt på konsumentpriset på el. Däremot finner vi ingen statistiskt signifikant effekt av avregleringen oavsett hur denna har operationaliserats. 
Tabell 5.1: Regressionsresultat från den reducerade prismodellen. (a) är modell där skatt inkluderas som en oberoende variabel, och (b) är en modell där skatten inte inkluderas som en oberoende variabel. $t$-värden inom parentes.

\begin{tabular}{|c|c|c|c|c|}
\hline \multirow{2}{*}{\begin{tabular}{|l|} 
Variabel \\
\end{tabular}} & \multicolumn{2}{|c|}{$\begin{array}{l}\text { Modell med diskret } \\
\text { dummy }\end{array}$} & \multicolumn{2}{|c|}{\begin{tabular}{|l|}
$\begin{array}{l}\text { Modell med logistisk } \\
\text { dummy }\end{array}$ \\
\end{tabular}} \\
\hline & (a) & (b) & (a) & (b) \\
\hline Konstant & $\begin{array}{l}-4.480 \\
(-0.70)\end{array}$ & $\begin{array}{l}-16.967 \\
(-3.84)\end{array}$ & $\begin{array}{l}-4.536 \\
(-(0.71)\end{array}$ & $\begin{array}{l}-14.879 \\
(-3.48)\end{array}$ \\
\hline Nederbörd(t) & $\begin{array}{l}-0.462 \\
(-1.88)\end{array}$ & $\begin{array}{l}-0.396 \\
(-1.51)\end{array}$ & $\begin{array}{l}-0.463 \\
(-1.89)\end{array}$ & $\begin{array}{l}-0.429 \\
(-1.67)\end{array}$ \\
\hline Nederbörd(t-1) & $\begin{array}{l}-0.450 \\
(-1.83) \\
\end{array}$ & $\begin{array}{l}-0.500 \\
(-1.91) \\
\end{array}$ & $\begin{array}{l}-0.450 \\
(-1.83) \\
\end{array}$ & $\begin{array}{l}-0.499 \\
(1.94) \\
\end{array}$ \\
\hline Temperatur & $\begin{array}{l}-0.065 \\
(-1.95)\end{array}$ & $\begin{array}{l}-0.14 \\
(-1.87)\end{array}$ & $\begin{array}{l}-0.07 \\
(-0.81)\end{array}$ & $\begin{array}{l}-0.147 \\
(1.94)\end{array}$ \\
\hline Kolpris & $\begin{array}{l}0.235 \\
(2.41) \\
\end{array}$ & $\begin{array}{l}0.302 \\
(3.03)\end{array}$ & $\begin{array}{l}0.238 \\
(2.44) \\
\end{array}$ & $\begin{array}{l}0.302 \\
(3.11)\end{array}$ \\
\hline $\mathrm{BNP}$ & $\begin{array}{l}1.023 \\
(1.91) \\
\end{array}$ & $\begin{array}{l}.104 \\
(6.96) \\
\end{array}$ & $\begin{array}{l}1.029 \\
(1.91) \\
\end{array}$ & $\begin{array}{l}1.947 \\
(5.87) \\
\end{array}$ \\
\hline Kärnkraft & $\begin{array}{l}-0.040 \\
(-2.38)\end{array}$ & $\begin{array}{l}-0.02 \\
(1.13)\end{array}$ & $\begin{array}{l}-0.038 \\
(-2.05)\end{array}$ & $\begin{array}{l}-0.011 \\
(-0.82)\end{array}$ \\
\hline Punktskatt* $(1+\text { moms })^{\mathrm{a}}$ & $\begin{array}{l}0.488 \\
(2.37)\end{array}$ & - & $\begin{array}{l}0.474 \\
(2.10)\end{array}$ & - \\
\hline Avreglering (0/1) & $\begin{array}{l}0.057 \\
(0.06) \\
\end{array}$ & $\begin{array}{l}0.11 \\
(1.19) \\
\end{array}$ & $\begin{array}{l}0.019 \\
(0.14) \\
\end{array}$ & \\
\hline Avreglering (logistisk) & & & $\begin{array}{l}0.019 \\
(0.14) \\
\end{array}$ & $\begin{array}{l}0.19 \\
(1.60)\end{array}$ \\
\hline R2-värde & 0.87 & 0.87 & 0.87 & 0.85 \\
\hline DW-stats & 1.73 & 1.74 & 1.73 & 1.75 \\
\hline
\end{tabular}

a i "punktskatt" ingår även certifikatsavgiften från och med 2003.

En jämförelse mellan modellerna (a) och (b) visar på ett intressant resultat vad gäller effekten av ökad efterfrågan på grund av ökad ekonomisk aktivitet (BNP). I modell (b), där "skatten" inte inkluderas som en oberoende variabel, ser vi att en ökning av BNP med 10 procent skulle innebära att konsumentpriset på el ökar med nära 20 procent (2.104). I modell (a), där "skatten" är med, ser vi att samma ökning av BNP leder till en betydligt lägre prisökning, cirka 10 procent (1.023). En mycket trolig förklaring till detta är att skattens utveckling över tid samvarierar kraftigt med BNP. Det betyder att om vi utesluter skatten är det troligt att effekten från BNP även inkluderar skatteeffekter. Med andra ord är det troligt att effekten från en BNP ökning även fångar upp effekten av en skatteförändring. ${ }^{25}$

\footnotetext{
${ }^{25}$ Korrelationen mellan skatt och BNP är 0.95 , vilket ställer till problem när båda är med i modellen. Problemet är att det är svårt att separera effekterna (s.k. multikollinearitet).
} 
En viktig fråga är naturligtvis hur pass robusta dessa resultat är. För att testa detta har bl.a. en alternativ modell med en kortare tidsperiod (1980-2010) också estimerats, och resultaten från denna bekräftar bilden av en icke-signifikant avregleringseffekt. Samma slutsats kan också dras då estimeringen baseras på en linjär modell; de efterfråge- och utbudspåverkande faktorerna har en statistiskt signifikant effekt på elpriset med det gäller inte för de två avregleringsvariablerna. De icke-signifikanta resultaten för de två avregleringsvariablerna består dock. Sammantaget visar detta att det finns litet empiriskt stöd i de data vi använt för att avregleringen per se haft någon signifikant effekt, vare sig positiv eller negativ, på konsumentpriset. ${ }^{26}$

Detta väcker naturligtvis frågan om varför konsumentpriset på el ökat så markant sedan början av 2000-talet. Vår modell indikerar ett antal variabler som skulle bidra till att förstå utvecklingen. Vi har redan konstaterat att skattenivåerna har en viktig betydelse för utfallet, och dessa har ökat kontinuerligt sedan början av 1990-talet (inte minst som ett resultat av införandet av moms på el 1991). I Figur 5.3 visas dessutom utvecklingen för ytterligare tre variabler: BNP, kolpriset samt kärnkraftsproduktionen (här uttryckt som index där Index $100=1996$ ).
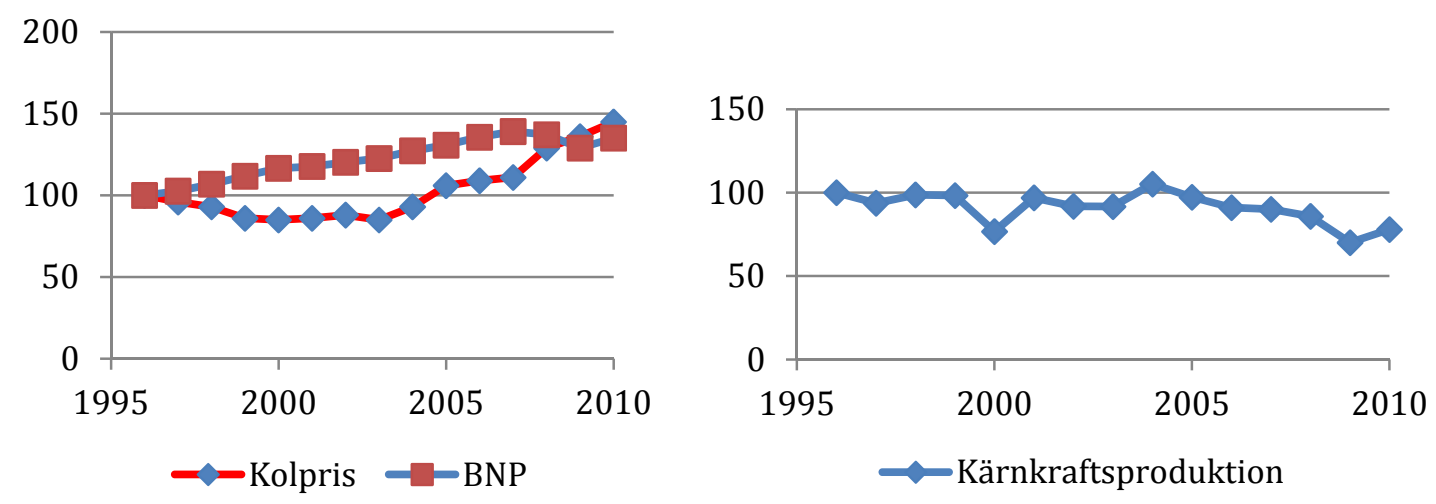

Figur 5.3: Utvecklingen av BNP, kolpris och kärnkraftsproduktion, 1996-2010 (Index $100=$ 1996).

Figur 5.3 visar att under perioden 1996-2010 ökade det reala värdet på BNP ökat med ca 35 procent, och våra ekonometriska analyser tyder på att utan denna ökning hade elpriset (allt annat lika) varit lägre. Samma figur visar också att sedan 2005 har vi sett en markant ökning i det europeiska kolpriset, och eftersom kolkraft till stora delar bestämmer marginalkostnaden på den nordiska elmarknaden har det med stor sannolikhet haft betydelse för elprisökningarna under de senaste 5-7 åren. Den högra delen av Figur 5.3 visat hur kärnkraftens tillgänglighet gradvis reducerats under perioden, och detta har också bidragit till de ökade elpriserna under de senaste tio åren. Till detta kan läggas att vissa av topparna i elpriset (t.ex. vintern 2002/03) kan förklaras av underskott i vatten-

\footnotetext{
${ }^{26}$ Lundgren (2009) analyserar avregleringen 1996 genom att jämföra prisbanan på el (Nordpoolpriset) med en beräknad prisbana som skulle ha gällt vid en reglerad marknad. Han finner att priset efter avregleringen i genomsnitt är lägre, men mer volatilt än det pris som skulle ha gällt om marknaden varit reglerad. Han gör dock inget formellt statistiskt test på avregleringens effekter.
} 
magasinen. Det finns dock ingen långsiktig trend som pekar mot en långsiktig reduktion av eltillförseln från vattenkraften.

Ovan har vi analyserat effekterna på konsumentpriset (inklusive skatter) som en följd av förändringar $\mathrm{i}$ de fundamentala utbuds- och efterfrågefaktorerna samt avregleringen. Den övergripande slutsatsen var att förändringar i efterfrågan och utbud kan förklara utvecklingen av konsumentpriserna och att skattningen för avregleringen visserligen är positiv men inte statistiskt signifikant. Således kan man säga att avregleringen inte tycks ha haft någon effekt, vare sig positiv eller negativ, på konsumentpriset på el.

Som vi visat tidigare består en stor del av konsumentpriset för el av skatter och avgifter. Förutom punktskatten på el som har stigit trendmässigt över tiden så utgår moms på el, och från 1991 utgår även moms på punktskatten. År 2003 infördes dessutom elcertifikatsystemet, vilket innebär en extra avgift i konsumentledet. År 1970 var den totala konsumtionsskatten på el knappt 4 öre per kWh i 2010 års penningvärde. År 2010 uppgick den totala konsumtionsskatten till cirka 57 öre per $\mathrm{kWh}$.

Detta betyder inte att konsumentpriset på el nödvändigtvis har stigit i motsvarande grad. Skälet är att en ökad skatt, som ökar konsumentens kostnad för el, innebär att efterfrågan på el också minskar, vilket tenderar att pressa ner jämviktspriset exklusive skatt (säljarens pris). Hur stor effekten av en skattehöjning blir på jämviktspriset beror helt och hållet på utbudskurvans lutning. Antag exempelvis att utbudskurvan är helt vertikal, dvs. utbudet av el är fullständigt okänsligt för prisförändringar. Det betyder de facto att skatten kan övervältras fullständigt på säljaren, säljaren bär hela skattebördan. Det betyder att den direkta skatteeffekten som drabbar konsumenten motverkas fullständigt av ett lägre pris på råkraftsmarknaden. Om det omvända gäller, dvs. att utbudet av el är mycket priskänsligt (flack utbudskurva), kommer konsumenterna att få bära en stor del av skattebördan $\mathrm{i}$ och med att skattehöjningen till stor faller på konsumenterna. Resultaten i tabell 5.1 indikerar just detta att man delar på skattebördan eftersom skattelasticiteten här är större än noll men mindre än 1. En tolkning är att om skatten ökar med 10 procent så ökar konsumentpriset med knappt 5 procent (0.488).

Som ett komplement till resultaten ovan har vi estimerat motsvarande modell men med pris exklusive skatt som den beroende variabeln. Vi förväntar oss nu en icke-positiv effekt av skatten, eftersom skatten förväntas minska efterfrågan, vilket i sin tur bör vara prisdämpande på priset exklusive skatter. ${ }^{27} \mathrm{I}$ övrigt förväntar vi oss liknande effekter som resultaten ovan. Resultaten från denna alternativa modell redovisas i tabell 5.2.

\footnotetext{
${ }^{27}$ Den modell vi skattar här kan ses som en loglinjär approximation till en icke-linjär prisekvation.
} 
Tabell 5.2: Regressionsresultat från den reducerade prismodellen, pris exklusive skatter och avgifter. (a) är modell med skatt som oberoende variabel, och (b) är modell utan skatt som oberoende variabel. $t$-värden inom parentes.

\begin{tabular}{|c|c|c|c|c|}
\hline \multirow{2}{*}{ Variabel } & \multicolumn{2}{|c|}{$\begin{array}{l}\text { Modell med diskret } \\
\text { dummy }\end{array}$} & \multicolumn{2}{|c|}{$\begin{array}{l}\text { Modell med logistisk } \\
\text { dummy }\end{array}$} \\
\hline & (a) & (b) & (a) & (b) \\
\hline Konstant & $\begin{array}{l}-5.296 \\
(-0.58)\end{array}$ & $\begin{array}{l}-10.515 \\
(-2.08)\end{array}$ & $\begin{array}{c}-5.349 \\
(-0.59)\end{array}$ & $\begin{array}{l}-9.589 \\
(-1.67)\end{array}$ \\
\hline Nederbörd(t) & $\begin{array}{l}-0.611 \\
(-1.75) \\
\end{array}$ & $\begin{array}{l}-0.583 \\
(-1.69) \\
\end{array}$ & $\begin{array}{l}-0.609 \\
(-1.75)\end{array}$ & $\begin{array}{l}-0.595 \\
(-1.73)\end{array}$ \\
\hline Nederbörd(t-1) & $\begin{array}{l}-0.563 \\
(-1.61) \\
\end{array}$ & $\begin{array}{l}-0.583 \\
(-1.69) \\
\end{array}$ & $\begin{array}{l}-0.562 \\
(-1.61) \\
\end{array}$ & $\begin{array}{l}-0.581 \\
(1.69) \\
\end{array}$ \\
\hline Temperatur & $\begin{array}{l}-0.155 \\
(-1.36)\end{array}$ & $\begin{array}{l}-0.189 \\
(-1.85)\end{array}$ & $\begin{array}{l}-0.157 \\
(-1.34)\end{array}$ & $\begin{array}{l}-0.189 \\
(-1.86)\end{array}$ \\
\hline Kolpris & $\begin{array}{l}0.452 \\
(3.25)\end{array}$ & $\begin{array}{l}0.479 \\
(3.64)\end{array}$ & $\begin{array}{l}0.455 \\
(3.29)\end{array}$ & $\begin{array}{l}0.481 \\
(3.70) \\
\end{array}$ \\
\hline BNP & $\begin{array}{l}1.201 \\
(1.57)\end{array}$ & $\begin{array}{l}1.650 \\
(4.15)\end{array}$ & $\begin{array}{l}1.204 \\
(1.57)\end{array}$ & $\begin{array}{l}1.581 \\
(3.55) \\
\end{array}$ \\
\hline Kärnkraft & $\begin{array}{l}-0.044 \\
(-1.86)\end{array}$ & $\begin{array}{l}-0.034 \\
(1.81)\end{array}$ & $\begin{array}{l}-0.043 \\
(-1.62)\end{array}$ & $\begin{array}{l}-0.032 \\
(-1.65)\end{array}$ \\
\hline Punktskatt* $(1+\text { moms })^{\mathrm{a}}$ & $\begin{array}{l}0.204 \\
(0.69)\end{array}$ & - & $\begin{array}{l}0.194 \\
(0.60)\end{array}$ & - \\
\hline Avreglering (0/1) & $\begin{array}{l}0.007 \\
(0.04)\end{array}$ & $\begin{array}{l}0.04 \\
(0.30)\end{array}$ & - & - \\
\hline Avreglering (logistisk) & - & - & $\begin{array}{l}0.003 \\
(0.01) \\
\end{array}$ & $\begin{array}{l}0.07 \\
(0.46) \\
\end{array}$ \\
\hline R2-värde & 0.58 & 0.49 & 0.48 & 0.49 \\
\hline DW-stats & 1.99 & 1.99 & 1.99 & 1.99 \\
\hline
\end{tabular}

a i "punktskatt" ingår även certifikatsavgiften från och med 2003.

Som framgår av tabell 5.2 är de kvalitativa resultaten nästan identiska med resultaten i tabell 5.1. Dock kan man konstatera att estimaten är något mer oprecisa i tabell 5.2. Vi kan också konstatera att problemet med multikollinaritet mellan BNP och skatt kvarstår och gör resultaten något svårtolkade vad avser effekter av skatteförändringar respektive förändringar i BNP. Vi ser också att parametern för "punktskatt" är positiv, vilket vi inte förväntat oss, dock är den inte signifikant skild från noll. En möjlig delorsak till detta är att denna variabel samvarierar med flera av variablerna, inte minst BNP. Dock kan man möjligen dra slutsatsen från resultaten i tabell 5.1 och 5.2 att skatten till största delen bärs av konsumenterna av el. Slutsatsen följer av att vi har en positiv och statistiskt signifikant effekt av skatten på konsumentpriset (tabell 5.1), men en liten och ej signifikant effekt på priset exklusive skatt (tabell 5.2). Denna slutsats stöds av att efterfrågan på el typiskt är relativt prisoelastisk. 


\subsection{En ekonometrisk analys av elprisets utveckling under perioden 1996-2010}

Syftet med detta avsnitt är att undersöka om förändringar i områdespriset för Sverige på Nordpool kan förklaras av förändringar i de fundamentala faktorer som diskuterats tidigare (efterfrågan och utbud). Denna analys skiljer sig med andra ord från den i avsnitten 5.2 och 5.3 genom att vi nu: (a) endast analyserar producentpriser; samt (b) utgår från månatliga snarare än årliga data. Det pris vi försöker förklara är det områdespris som gäller för Sverige. I figur 3.2 i avsnitt 3 redogjordes för hur Sverigepriset och systempriset utvecklats månad för månad sedan 1996. Avvikelser mellan de två priserna indikerar på att den svenska marknaden inte fullt ut är integrerad med den övriga nordiska marknaden. Tre viktiga observationer kan göras från figur 3.2. Den första är att det inte finns någon enkel linjär trend för prisutvecklingen sett över hela tidsperioden. Fram till 2002 föll det reala priset, för att därefter stiga. För det andra tycks volatiliteten ha ökat under senare delen av perioden. För det tredje, volatiliteten i det svenska priset är högre än motsvarande volatilitet i systempriset, vilket indikerar att det kan finnas flaskhalsar i överföringssystemet mellan de olika prisområdena.

Ett sätt att identifiera perioder med flaskhalsar är att beräkna skillnaden mellan systempris och områdespris på Nordpool. Är exempelvis Sverigepriset högre än systempriset indikerar det att vi i Sverige inte kan köpa all el som efterfrågas till det gällande priset, systempriset, beroende på att det inte finns kapacitet att överföra elen från området där det finns produktion till det område som efterfrågar mer el. Det betyder i sin tur att priset inom området med överskottsefterfrågan kommer att stiga, relativt systempriset.

I figur 5.4 redovisas prisskillnaden mellan sverigepriset och systempriset. ${ }^{28}$ Som framgår är det ett tydligt mönster i så måtto att prisskillnaden är mer volatil under senare delen av 2000-talet. En tolkning är att begränsningen i att överföra el mellan olika prisområden har ökat över tiden. En enkel regressionsanalys (se appendix) visar att prisdifferensen ökar i perioder med ökad efterfrågan och minskar med ökat utbud av el, vilket man kan förvänta sig. Om utbudet är begränsat och efterfrågan hög i Sverige uppstår ett importbehov, men om detta inte kan tillgodoses på grund av flaskhalsar i överföringskapaciteten reflekteras detta i stället via högre priser i Sverige.

Det finns en diskussion om att flaskhalsproblematiken inte bara är fråga om en ren marknadseffekt, utan att de också till viss del skapas för att manipulera områdespriser. Exempelvis skulle Svenska Kraftnät kunna påverka det svenska (och danska) områdespriset genom att helt enkelt försvåra överföring av el från Sverige till Danmark. I en debattartikel i DN den 10 oktober 2010 hävdar energiforskare att just detta har skett från till annan (Fridolfsson och Tangerås, www.dn.se/debatt/norge-lag-bakom-vinternsrekordhoga-svenska-elpriser). De extrema prisspikar som vi såg vissa timmar vintern 2010/2011 var, menar författarna, inte bara var en följd av fysisk överförings-brist utan även en följd av att Statnett, som ansvarar för det norska stamnätet, helt enkelt strypte tillförseln till Sverige i syfte att hålla nere priset för norska konsumenter. Liknande misstankar riktas i artikeln mot Svenska Kraftnät som i vissa tider misstänks ha gjort liknande manövrar i elutbytet mellan Sverige och Danmark.

\footnotetext{
${ }^{28}$ Det betyder dock inte att varje timme eller dag en sådan månad karakteriseras av kapacitetsbrist, eftersom det pris vi analyserar är genomsnittligt månadspris.
} 


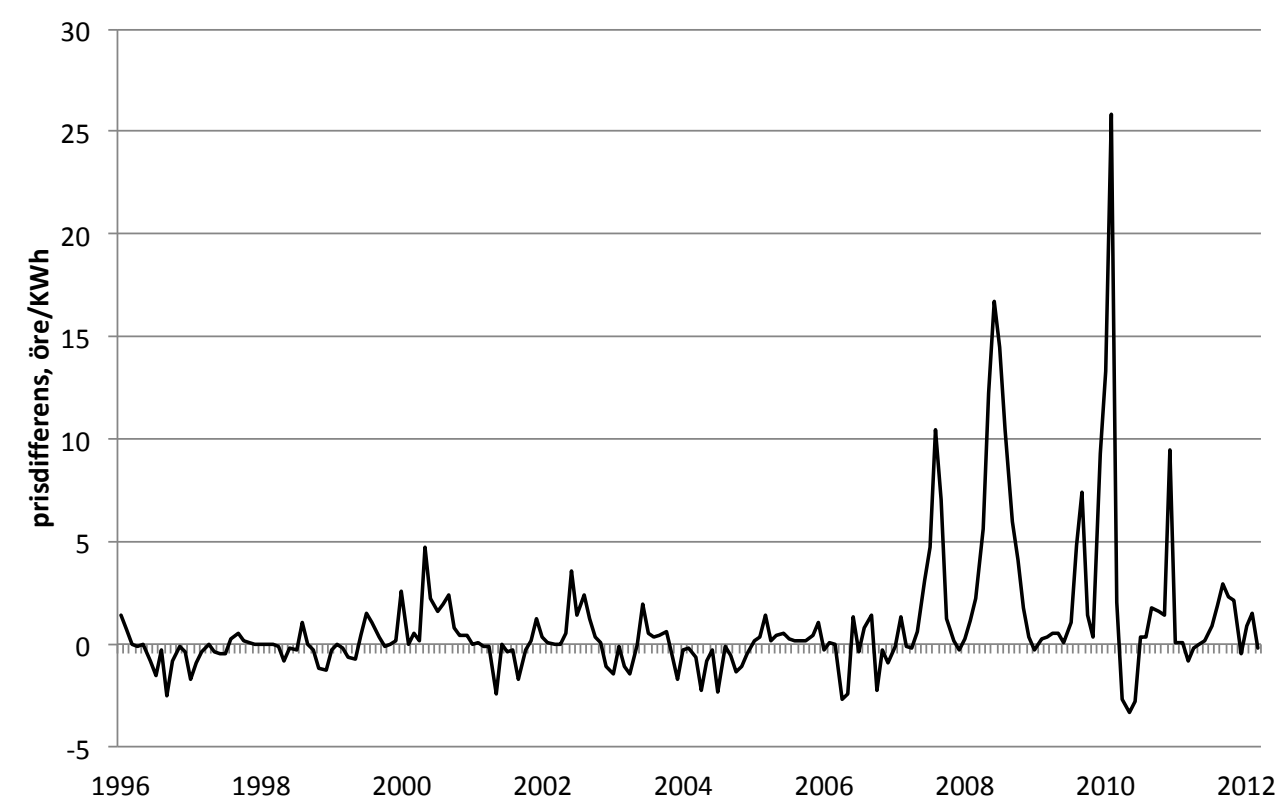

Figur 5.4: Prisdifferens i elpris mellan svenskt områdespris och nordiskt systempris, öre/kWh.

Den modell vi specificerar för månadsmodellen för elpriset på Nordpool grundar sig på samma teoretiska resonemang som för den årliga modellen för konsumentpriset; prisnivå och förändringar av priset antas kunna förklaras av fundamentala faktorer som kan härledas till förändringar i utbud (marginalkostnader) av el och efterfrågan efter el. De utbudsfaktorer som vi här tar i beaktande är tillgänglighet av kärnkraftsel (mätt som produktion), grad av fyllnad i det vattenkraftssystemet, samt kolpris. De efterfrågefaktorer vi beaktar är ekonomisk aktivitet (mätt som industriproduktionsindex) och temperatur. Till denna grundläggande, eller fundamentala, struktur försöker vi kontrollera för flaskhalsar genom att lägga till en variabel som tar värdet ett om prisdifferensen en given period är statistiskt skild från noll, och noll annars. Vi antar här att förekomsten av flaskhalsar påverkar den kortsiktiga dynamiken i prisutvecklingen.

Mer exakta definitioner och deskriptiv analys för såväl beroende variabel (pris) och de oberoende variablerna tillhandahålls av författarna på bebäran. En slutsats som kan dras från den deskriptiva analysen är att ingen av variablerna tycks vara stationära. De stationaritetstest som görs (Dickey-Fuller test) implicerar att vi inte kan förkasta att variablerna är integrerade av ordning ett. Det betyder i praktiken att första differenserna är stationära och att en linjär kombination av variablerna kan vara stationär. Modellmässigt betyder det att vi i princip kan specificera en så kallad felkorrigeringsmodell, som består av ett långsiktigt linjärt samband mellan pris och de oberoende utbuds- och efterfrågevariablerna, samt ett dynamiskt mer kortsiktigt samband som beror på dels avvikelser av priset från det långsiktiga sambandet och/eller för att någon av de underliggande fundamentala variablerna ändras mellan föregående och innevarande tidsperiod (kortsiktig dynamik). ${ }^{29}$

\footnotetext{
${ }^{29}$ Icke-stationära dataserier som är kointegrerade kan representeras på felkorrigeringsform (Engle och Granger, 1987), vilket gör att en felkorrigeringsmodell är lämpad här eftersom de flesta av de tidsserier vi använder är våra dataserier är icke-stationära.
} 
Med andra ord, felkorrigeringsmodellen består av två ekvationer som fångar upp såväl det långsiktiga sambandet som det kortsiktiga. Vi kan skriva det långsiktiga sambandet som:

$$
p_{t}^{\text {STO }}=a_{0}+a_{1} X_{t}^{s}+a_{2} X_{t}^{d}+\varepsilon_{t}
$$

där $p^{S T O}$ är områdespriset för Sverige, $X^{s}$ är en vektor av utbudspåverkande variabler, $X^{d}$ en vektor av efterfrågepåverkande variabler. Vektorerna $a_{1}$ och $a_{2}$ är de korresponderande parametervektorerna. Slutligen, $\varepsilon$ är den del av prisvariationen som inte kan förklaras av modellens variabler.

Ekvation (5.2) representerar därmed det långsiktiga, eller statiska, sambandet mellan pris och de utbuds- och efterfrågepåverkande faktorerna. Avvikelser från det statiska, eller långsiktiga, sambandet kan nu skrivas som:

$$
p_{t}^{\text {STO }}-\left(a_{0}+a_{1} X_{t}^{s}+a_{2} X_{t}^{d}\right)=\varepsilon_{t}
$$

En förutsättning för att det skall finnas ett långsiktigt samband är att avvikelsen, eller feltermen, är stationär, dvs. att den över tiden hela tiden tenderar tillbaka till samma värde (noll). Uttryckt annorlunda kan man säga att även om variablerna i modellen är icke-stationära var och en så kan en kombination av dem vara stationär. Ett klassiskt exempel är inkomst och konsumtion som båda är icke-stationära tidsserier, men där en linjär kombination av de två är stationär (på lång sikt konsumerar man hela inkomsten, så skillnaden de emellan blir noll).

Givet det långsiktiga sambandet i ekvation (5.2) kan "felkorringeringsekvationen", den dynamiska ekvationen, skrivas som:

$$
\Delta p_{t}^{\text {STO }}=b_{0}+b_{1} \Delta X_{t}^{s}+b_{2} \Delta X_{t}^{d}+\delta D_{t}+\theta \varepsilon_{t-1}
$$

Parametern $\theta$ fångar upp och "korrigerar" för avvikelser från det långsiktiga sambandet. Antag, exempelvis, att $\varepsilon_{t-1}>0$, vilket betyder (från ekvation 5.2) att $p_{t-1}$ är högre än det långsiktiga jämviktspriset. Det betyder att vi bör förvänta oss att priset faller ner mot det långsiktiga priset till nästa period, dvs., $\Delta p_{t}<0$, vilket i sin tur betyder att $\theta<0$. Med andra ord kan vi testa rimligheten av modellen genom att testa om $\theta$ är mindre än noll eller inte. Är den inte det så kan vi förkasta modellen. Variabeln $D$ är det mått på kapacitetsbrist i elöverföring till och från Sverige som används. $D$ tar värdet "1" då skillnaden mellan det svenska priset och systempriset överstiger 2,5 gånger standardavvikelsen för prisdifferensen. Vi förväntar oss att $\delta$ är positiv av de skäl vi diskuterat.

Resultaten från modellkörningarna redovisas i tabellerna 5.2-5.4. I tabell 5.2 redovisas det statiska, eller långsiktiga, kointegrerande sambandet mellan elpris och de utbudsoch efterfrågedrivande faktorerna. Motsvarande elasticiteter, utvärderade i medelvärdet för respektive variabel, redovisas i tabell 5.3. Resultaten från den dynamiska modellen, den så kallade felkorrigeringsmodellen, redovisas i tabell 5.4. 
Tabell 5.2. Regressionsresultat långsiktig (statisk)

\begin{tabular}{|l|l|l|l|}
\hline Variabel & Koefficient & Standardavvikelse & t-värde \\
\hline C & 28.74 & 8.55 & 3.36 \\
\hline Kärnkraft & -0.00029 & 0.0001 & -2.99 \\
\hline Magasinfyllnad & -0.061 & 0.041 & -1.46 \\
\hline Kolpris & 0.208 & 0.019 & 11.12 \\
\hline Industriproduktion & 0.041 & 0.063 & 0.65 \\
\hline Temperatur & -0.677 & 0.153 & -4.39 \\
\hline R2 & 0.50 & & \\
\hline DW & 0.40 & & \\
\hline DF-test1 & $-0.19($ alpha) & 0.04 & -4.12 \\
\hline 1 Dickey-Fuller test: $\Delta \varepsilon=\left(\right.$ alpha+1) $\varepsilon_{\mathrm{t}-1}$ & \\
\hline
\end{tabular}

Resultaten i tabell 5.2 visar att minskad tillgänglighet av kärnkraft pressar upp priset inom det svenska elområdet, och att detsamma gäller för kolpriset. Stiger priset på kol så ökar elpriset. Vi ser också att effekten på priset av mer vatten i magasinen visserligen är negativ, men att effekten inte är statistiskt signifikant skild från noll. Även på efterfrågesidan ser vi att effekterna är de förväntade, dvs. högre temperatur leder till lägre elpris, och högre industriproduktion tenderar att pressa upp priset, även om den senare effekten inte är statistiskt signifikant skild från noll. Från Dickey-Fuller testet (DF-test) kan vi inte förkasta hypotesen att det finns ett långsiktigt kointegrerande samband mellan variablerna. Sammantaget uppvisar resultaten i tabell 5.2 liknande resultat som analysen av det årliga konsumentpriset, dvs. att fundamentala efterfrågeoch utbudsfaktorer kan förklara den långsiktiga prisutvecklingen.

Elasticiteterna i tabell 5.3 visar med hur många procent elpriset förändras om variabeln $\mathrm{i}$ den första kolumnen ändras med säg 10 procent. Således ser vi att om kolpriset stiger med 10 procent, exempelvis som en följd av högre pris på utsläppsrätter, så ökar elpriset på den svenska marknaden med cirka 6 procent. Man kan konstatera att priset i sverige är mest känsligt för förändringar i kolpris och kärnkraftens tillgänglighet. Detta verifierar i vart fall delvis resultaten från simuleringarna i avsnitt 4

Tabell 5.3. Elasticiteter, långsiktiga (utvärderade i medelvärdet).

\begin{tabular}{|l|r|}
\hline Variabel & Elasticitet \\
\hline Kärnkraft & -0.51 \\
\hline Magasinfyllnad & -0.11 \\
\hline Kolpris & 0.69 \\
\hline Industriproduktion & 0.13 \\
\hline Temperatur & -0.11 \\
\hline
\end{tabular}


Tabell 5.4. Regressionsresultat dynamisk (felkorrigering) ekvation.

\begin{tabular}{|l|l|l|l|}
\hline Variabel & Koefficient & Standardavvikelse & t-värde \\
\hline $\mathrm{C}$ & -0.36 & 0.47 & -0.74 \\
\hline$\Delta$ Kärnkraft & -0.002 & 0.0007 & -2.89 \\
\hline$\Delta$ Magasinfyllnad & -0.02 & 0.0443 & -0.45 \\
\hline$\Delta$ Kolpris & 0.09 & 0.062 & 1.53 \\
\hline$\Delta$ industriproduktion & 0.0003 & 0.034 & 0.01 \\
\hline$\Delta$ Temperatur & -0.639 & 0.128 & -4.96 \\
\hline$D$ & 11.44 & 2.14 & 5.34 \\
\hline EC & -0.169 & 0.043 & -3.88 \\
\hline R2 & 0.19 & & \\
\hline$D W$ & 1.50 & & \\
\hline$\Delta X=X_{t}-X_{t-1}$ & & & \\
EC $=\mathrm{e}_{t-1}$ & & &
\end{tabular}

Resultaten från den kortsiktiga, eller dynamiska, modellen visar att de fundamentala faktorerna har den effekt man kan förvänta sig, och att det sker en anpassning av priset på kort sikt mot det långsiktiga jämviktspriset (EC). Värt att notera är att effekten av förändringar i industriproduktion ej är statistiskt signifikant för anpassningen mot den långsiktiga trenden, även om tecknet är det förväntade, dvs. att ökad industriproduktion tenderar att driva upp priset. Vad man kan konstatera, även från resultaten från den dynamiska modellen, är att förändringar i kärnkraftstillgänglighet och kolpris är de utbudspåverkande faktorer som har störst effekt på priset även på kort sikt, och att temperatur är den efterfrågefaktor som tycks ha störst påverkan på priset.

Resultaten i tabell 5.3 visar även att det approximativa måttet på flaskhalsar i eldistributionen har stark effekt på priset i Sverige. Resultatet indikerar att om vi går från en situation där det inte finns några kapacitetsbrister till en situation med kapacitetsbrist så ökar priset i Sverige med drygt 10 öre/kWh från en period till en annan. ${ }^{30}$ Genom att substituera in ekvation 5.3 i 5.4 får vi ett explicit dynamiskt uttryck för hur priset utvecklas över tid:

$$
p_{t}=b_{0}-a_{0} \theta+b_{1} X_{t}^{s}+b_{2} X_{t}^{s}-\left(b_{1}+\theta a_{1}\right) X_{t-1}^{s}-\left(b_{2}+\theta a_{2}\right) X_{t-1}^{d}+\delta D_{t}+(\theta+1) p_{t-1}+u_{t}
$$

Priset i en given period kommer alltså att beror på de fundamentala utbuds-och efterfrågefaktorerna i samma och föregående period (månad), priset föregående månad, samt på om det finns kapacitetsbrist i elöverföring eller inte. Genom att sätta in de skattade parametervärdena och värden på de ingående variablerna i ekvationen ovan kan vi få en uppfattning om hur väl modellen "predikterar" den faktiska prisutvecklingen. Resultatet redovisas grafiskt i figur 5.5.

\footnotetext{
${ }^{30}$ Det bör noteras att måttet på kapacitetsbrist är grovt och fångar därmed kanske inte olika grader av kapacitetsbrist. För att mer exakt fånga effekten av eventuella kapacitetsbrister hade vi i princip behövt data för hur stor kapacitet det finns mellan samtliga områden inom det nordiska systemet.
} 


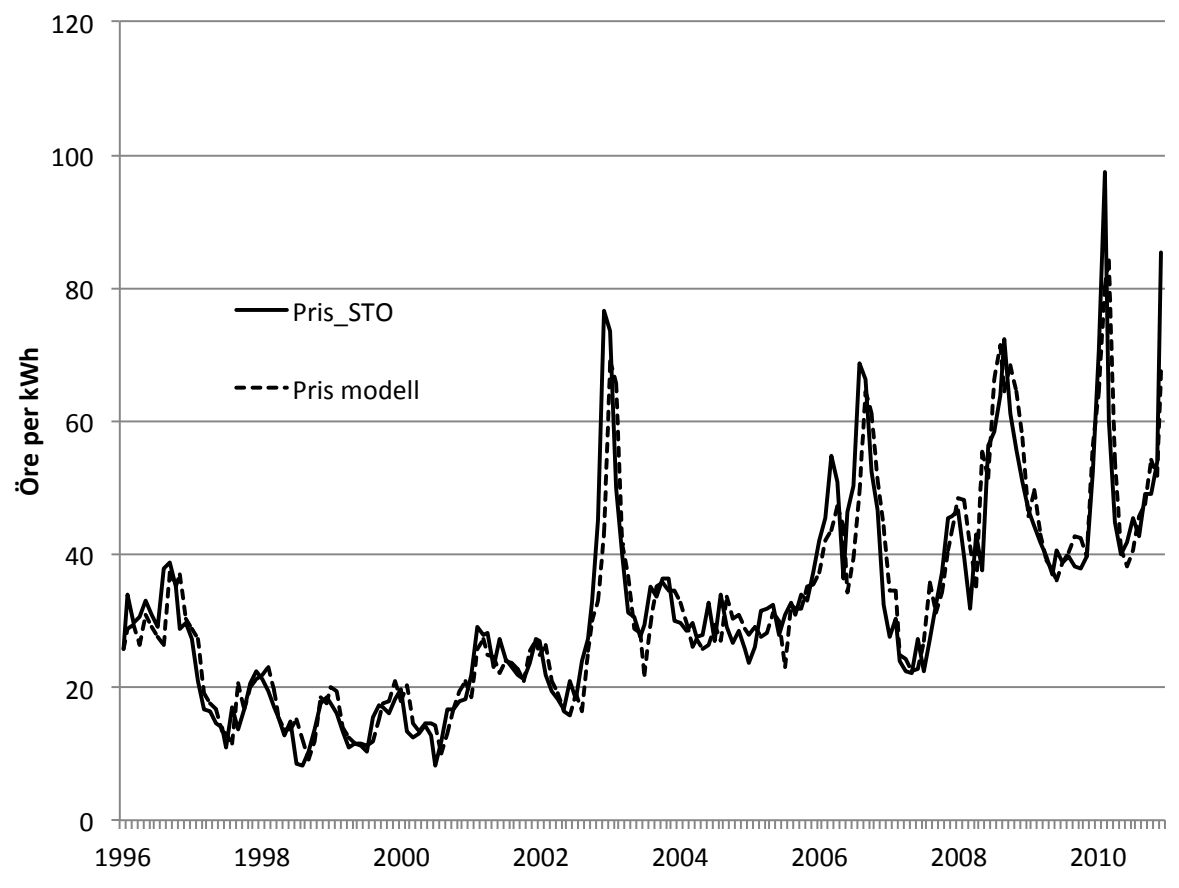

Figur 5.5: Faktiskt och av modellen uppskattat elpris för Sverige 1996-2010, öre/kWh.

Från figur 5.5 ser vi att modellanpassningen är relativt god, vilket är en indikation på att de fundamentala variablerna är viktiga förklaringsvariabler för elprisutvecklingen. Dock kan vi se att modellen inte helt fångar upp de allra högsta pristopparna. Med andra ord, vissa månader har det faktiska priset varit betydligt högre än vad som kan förklaras av de fundamentala variablerna och vårt mått på flaskhalsar. En möjlig förklaring till detta är att den variabel vi använt för att fånga upp flaskhalsar i eldistributionssystemet inte lyckas göra det fullt ut. Andra förklaringar är naturligtvis att vi saknar viktiga variabler. Sammantaget kan man dock konstatera att modellen tycks fungera väl. Dels har parameterskattningarna förväntat tecken, dels är förklaringsgraden relativt bra.

Sammanfattningsvis kan vi konstatera att den modell som specificerats och estimerats förklarar prisutvecklingen relativt bra. Vidare att resultaten i stora drag leder till liknande slutsatser som de som drogs från den årliga modellen vad gäller effekterna av de fundamentala faktorerna. Ytterligare en slutsats är att fysisk överföringskapacitet och hur man hanterar denna i varje land troligen har stor betydelse för priserna inom de olika prisområdena. Här har vi använt ett enkelt approximativt mått på flaskhalsar, ochd etta visar sig ha stor betydelse för priset. Här anser vi dock att en fördjupad analys vore värdefull.

\section{Slutsatser}

Syftet med denna rapport har varit att med hjälp av ekonomisk teori och ekonometriska metoder undersöka vilka faktorer som historiskt påverkat utvecklingen av elpriset i Sverige. En viktig bakgrund till studien är de prishöjningar som svenska konsumenter drabbats av under de senaste 10-15 åren. Det är av centralt intresse att förstå vad som kan förklara denna utveckling, t.ex. vilken betydelse avregleringen, skatter på el samt elcertifikatsystemet haft. 
Inledningsvis presenteras samt tillämpas en enkel numerisk modell av den nordiska elmarknaden. Den belyser elmarknadens funktionssätt på ett transparent sätt och kan användas för att illustrera de möjliga priseffekterna av olika förändringar på marknaden. Analysen visar bl.a. att elmarknaden "opererar" inte sällan längs en relativt brant (prisokänslig) del av utbudskurvan, vilket innebär kraftiga prissvängningar då efterfrågan förändras (t.ex. över årstiderna). Ett illustrativt exempel på det är pristoppen under vintern 2002/2003 då fyllnadsgraden i vattenmagasinen låg på en historiskt sett mycket låg nivå.

I rapporten används modellen för att simulera effekterna av en avveckling av den svenska kärnkraften samt elcertifikatsystemets effekter på elpriset. En avveckling av kärnkraften i Sverige innebär en tydlig begränsning av utbudet på den nordiska elmarknaden, och de ekonomiska effekterna är stark avhängiga hur känslig efterfrågan är för prisförändringar. Ju mindre priskänslig elefterfrågan är desto högre blir prisökningen av en kärnkraftsavveckling. Om kärnkraften läggs ned ökar vinsterna för de kvarvarande kraftslagen (t.ex. vattenkraften). Vår analys visar att kostnadsökningarna av att stänga ned kärnkraften inte kan kompenseras fullt ut av ökade vinster för kärnkraften. Detta är dock en fråga som bör analyseras i mer detalj, inte minst kopplat till förutsättningarna för större producenter att utöva marknadsmakt på grund av kors- och samägande av elkraftskapaciteten i Norden. Inte minst möjligheterna för bolagen att via investeringar - eller avsaknad av investeringar - påverka priset bör undersökas närmare.

Vår analys av elcertifkatsystemet visar att detta - och således den vindkraftsutbyggnad som är kopplad till detta system - leder till ett lägre systempris men totalt sett en högre kostnad för konsumenterna. Utbyggnaden av vindkraften kan dessutom på grund av sina intermittenta egenskaper leda till högre prisvolatilitet, vilket i sin tur påverkar de ekonomiska förutsättningarna för andra kraftkällor.

Den simuleringsmodell som vi använt utgår från antagandet att marknaden fungerar på ett effektivt sätt (dvs. under fri konkurrens), och därför använder vi ekonometriska metoder och data över verkligt marknadsutfall för att undersöka om det är ett rimligt antagande även i praktiken. De ekonometriska analyserna fokuseras på såväl den årliga utvecklingen av konsumentpriset (inklusive skatter) under perioden 1970-2010 samt den månatliga utvecklingen av producentpriset på Nordpool under perioden januari 1996 t.o.m. december 2010 .

I det första fallet testas explicit om avregleringen 1996 haft en prishöjande eller en prissänkande effekt på elpriset, men resultaten visar att avregleringens effekt (allt annat lika) på priset inte är statistiskt sett skilt från noll. I stället är det andra händelser som tydligare kan förklara prisutvecklingen under perioden, och dessa kan kopplas till förändringar i utbudet och efterfrågan på el. De ökade priserna sedan 2000 kan inte minst kopplas till en mindre tillgänglig (och dyrare) produktionskapacitet, t.ex. en lägre produktion från kärnkraften samt ett högre kolpris sedan 2005. Fyllnadsgraden i vattenmagasinen är också viktiga för att förstå variationerna över tiden. Vår analys bekräftar också att ökade skatter på el (moms, punktskatt, samt även elcertifikat) har haft en prishöjande effekt under de senaste 20 åren. Resultaten antyder också att konsumenterna har fătt bära den största delen av skattebördan medan effekterna på producentpriset varit små. 
Resultaten från den månatliga modellen bekräftar i stort de resultat som beskrivs ovan. Fundamentala utbuds- och efterfrågepåverkande faktorer (kärnkraftens tillgänglighet, kolpris, magasinfyllnad, temperatur, industrikonjunktur etc.) har påverkat elpriset sedan 1996. I denna del av analysen belyser vi även (implicit) effekterna av flaskhalsar i överföringskapaciteten mellan Sverige och de andra nordiska länderna (operationaliserat som prisdifferensen mellan Sverigepriset och systempriset). Resultatet indikerar att om vi går från en situation där det inte finns några kapacitetsbrister till en situation med kapacitetsbrist så ökar priset i Sverige med drygt 10 öre/kWh från en period till en annan (sett som ett månatligt genomsnittspris).

Sammanfattningsvis visar rapporten att den nordiska elmarknaden fungerar i stort som vi skulle förvänta oss av en effektiv marknad. Priset signalerar på ett tydligt sätt viktiga förändringar i efterfrågan och utbud, och utvecklingen i Sverige utgör inget undantag. De ökade konsumentpriserna kan till stor del förklaras av ett dyrare utbud i kombination med högre skatter. Ingen har uttryckt detta tydligare än den tidigare norske statsministern Kåre Willoch: "Om man önskar sig billig elektricitet så måste man bygga ut kapaciteten så mycket att det finns tillräckligt med el till den prisnivå som önskas.,"31

\section{Referenser}

Amundsen, E. S., och L. Bergman (2006). "Why has the Nordic Electricity Market Worked so Well?" Utilities Policy, Vol. 14, s. 148-157.

Andersson, B., och. L. Bergman (1995). "Market Structure and the Price of Electricity: An Ex Ante Analysis of the Deregulated Swedish Electricity Mar-ket," The Energy Journal, Vol. 16, Nr. 2, s. 97-109.

Bergman, L., T. Hartman, L. Hjalmarsson, och S. Lundgren (1994). Den nya elmarknaden, SNS förlag, Stockholm.

Blesel m.fl. (2008). Private Costs for Electricity and Heat Generation. Rapport från projektet "IEA and CASES - Cost Assessment for Sustainable Energy Markets". Project No 518294 SES6, Deliverable No D4.1.

Clemente, J., A. Montanes, och M. Reyes (1998). "Testing for Unit Root in Variables with a Double-change in the Mean," Economics Letters, Vol. 59, s. 175-182.

Damsgaard, N., och R. Green (2005). Den nya elmarknaden. Framgång eller misslyckande? SNS förlag, Stockholm.

Dempster, G. M. (2012). "Price Discovery in Electricity Markets," kommande i Encyclopedia of Energy, Natural Resource and Environmental Economics. Elsevier.

Energimyndigheten (2011). Vindkraftsstatistik 2011, ES 2012:02, Eskilstuna.

\footnotetext{
${ }^{31}$ Citatet är hämtat från en debattartikel av Lennart Hjalmarsson i Göteborgs-posten (mars 2011).
} 
Engle, R. F. and Granger, C. W. J. (1987). Co-integration and Error Correction:

Representation, Estimation, and Testing. Econometrica, 2, 251-276.

Fell, H. (2010). "EU ETS and Nordic Electricity: A CVAR Analysis," The Energy Journal, Vol. 31, Nr. 2, s. 1-25.

Fridolfsson, S-O, och T. P. Tangerås (2009). "Fungerar konkurrensen på elmarknaden?" Ekonomisk Debatt, Vol. 37, Nr. 8, s. 21-37.

Fridolfsson, S-O., och T. P. Tangerås (2011). Investeringar på elmarknaden - fyra förslag för förbättrad funktion, Rapport till Expertgruppen för miljöstudier 2011:5, Finansdepartementet, Stockholm.

Green, R., och N. Vasilakos (2011). The Long-Term Impact of Wind Power on Electricity Prices and Generating Capacity, Department of Economics Discussion Paper 11-09, University of Birmingham.

Hult. J., och Rydberg, S. (1989). Svensk Teknikhistoria. Gidlunds förlag.

Joskow, P. L. (2006). "Markets for Power in the United States: An Interim Assessment," The Energy Journal, Vol. 27, No. 1, pp. 1-36.

Kander, A., och M. Lindmark (2004). "Energy Consumption, Pollutant Emissions and Growth in the Long Run - Sweden during 200 years," European Review of Economic History, Vol. 8, s. 297-335.

Kwoka, J. (2008). "Restructuring the U.S. Electric Power Sector: A Review of Recent Studies," Review of Industrial Organization, Vol. 32, pp. 165-196.

Lundgren, J. (2009). "Consumer Welfare in the Deregulated Swedish Electricity Market," Frontiers in Finance and Economics, Vol. 2, s. 96-114.

Nilsson, I. (2009). Unit Root Tests and Structural Breaks in the Swedish Electricity Price, Magisteruppsats i nationalekonomi, Luleå tekniska universitet.

Mauritzen, J. (2010). What Happens when it's Windy in Denmark? An Empirical Analysis of Wind Power on Price Volatility in the Nordic Electricity Market, Discussion Paper, Norwegian School of Economics and Business Administration.

Pettersson, M., och P. Söderholm (2011). "Reforming Wind Power Planning and Policy: Experiences from the Nordic Countries," CESifo DICE Report: Journal for Institutional Comparisons, Nr. 4, s. 54-60.

Taber, J., D. Chapman, and T. Mount (2006). Examining the Effects of Deregulation on Retail Electricity Prices, Working Paper WP 2005-14, Department of Applied Economics and Management, Cornell University, USA. 